\title{
Surgical Engineering in Cranio-Maxillofacial Surgery: A Literature Review
}

\author{
Raphael Olszewski, DDS, MD, PhD \\ Oral and Maxillofacial Surgery Research Lab \\ Department of oral and maxillofacial surgery \\ Cliniques universitaires saint Luc \\ Université catholique de Louvain, Brussels, Belgium
}

Submitted March 2011. Accepted for publication August 2011

\begin{abstract}
A systematic review of the literature concerning surgical engineering in cranio-maxillofacial surgery was performed. A PubMed search yielded 1721 papers published between 1999 and 2011. Based on the inclusion/exclusion criteria, 1428 articles were excluded after review of titles and abstracts. A total of 292 articles were finally selected covering the following topics: finite element analysis $(n=18)$, computer-assisted surgery $(n=111)$, rapid prototyping models $(n=41)$, preoperative training simulators $(n=4)$, surgical guides $(n=23)$, image-guided navigation $(n=$ $58)$, augmented reality $(n=2)$, video tracking $(n=1)$, distraction osteogenesis $(n=19)$, robotics $(n=8)$, and minimal invasive surgery $(n=7)$. The results show that surgical engineering plays a pivotal role in the development and improvement of cranio-maxillofacial surgery. Some technologies, such as computer-assisted surgery, image-guided navigation, and three-dimensional rapid prototyping models, have reached maturity and allow for multiple clinical applications, while augmented reality, robotics, and endoscopy still need to be improved.
\end{abstract}

Keywords: engineering, maxillofacial, craniofacial, review, surgery

\section{INTRODUCTION}

Cranio-maxillofacial surgery (CMF) represents a broad range of sub-specialties, such as maxillofacial oncological surgery (resection of tumors and reconstruction of the site with different types of grafts), craniofacial corrective surgery of malformative syndromes (i.e., craniostenoses, or cleft lip palate), orthognathic surgery and distraction osteogenesis (to correct maxillomandibular dysmorphoses), maxillofacial trauma surgery and associated reconstructive maxillofacial surgery, and implantology. Surgical engineering in CMF surgery is present at all levels of the CMF clinical workflow, from diagnostic tools to preoperative planning, intra-operative guidance and transfer of preoperative planning to the operative theater. This literature review presents a broad overview of the implications of surgical engineering in CMF surgery.

*Tel: 003227645718, Fax: 003227645876, Email: raphael.olszewski@uclouvain.be 


\section{METHODS}

The literature search was performed on Medline PubMed by one researcher. The inclusion criteria were as follows: maxillofacial surgery, craniofacial surgery, implantology, distraction osteogenesis, orthognathic surgery, cleft lip palate surgery, traumatology, finite elements analysis, technology, robotics, virtual reality, augmented reality, haptic, computer-assisted surgery, computer-assisted surgical planning, computer-assisted guides, rapid prototyping, three-dimensional (3D) facial morphology, maxillofacial simulators, maxillofacial endoscopy, maxillofacial surgical hardware, cranioplasty, craniotomy, image-guided surgery, CMF navigation, endoscopy, temporomandibular joint, facial nerve, virtual occlusion, holography, CT scanner, and MRI. The exclusion criteria consisted of animal studies, in vitro studies, tissue engineering, prosthetics, orthodontics, dentistry, laser surgery, laser scanner, piezosurgery, plates, facial protection, jaw tracking, and telemedicine. Articles without an abstract were also excluded.

We used two main search formulas. The first formula was constructed for a broad research of articles dealing with surgical engineering and craniofacial surgery. This formula was formed by association between MeSH Terms (surgical procedures, operative, engineering, and skull) and the following free text words: surgical engineering AND cranial ((("surgical procedures, operative"[MeSH Terms] OR ("surgical"[All Fields] AND "procedures"[All Fields] AND “operative"[All Fields]) OR “operative surgical procedures"[All Fields] OR "surgical”[All Fields]) AND (“engineering"[MeSH Terms] OR “engineering”[All Fields])) AND ("skull”[MeSH Terms] OR “skull”[All Fields] OR “cranial”[All Fields]) AND "humans”[MeSH Terms]). The only limit was human studies. No limits were set on the language or date. We obtained a total of 334 articles, of which 314 were excluded based on the title and the abstract. Twenty articles were selected for review.

The second main formula was constructed to find articles about surgical engineering and maxillofacial surgery. We preferred to use the word "technology" in the second formula to search specifically for articles aimed at surgical engineering instead of tissue engineering. We used an association between MeSH Terms (surgery, oral; and technology) and the following free words: maxillofacial surgery technology (("surgery, oral"[MeSH Terms] OR ("surgery"[All Fields] AND "oral"[All Fields]) OR "oral surgery"[All Fields] OR ("maxillofacial"[All Fields] AND "surgery”[All Fields]) OR "maxillofacial surgery"[All Fields]) AND ("technology"[MeSH Terms] OR “technology”[All Fields])) AND ("humans"[MeSH Terms] AND "2001/02/22”[PDat] : "2011/02/19"[PDat]). The first limit was human studies, and the second limit was to search over the last ten years. No limits were set on the language. We found a total of 967 articles, and 835 of them were excluded based on title-abstract sifting. The remaining 131 were selected for review. To complete the general broad search, we added seven specific formulas based on MeSH terms and free terms:

1. finite element analysis AND maxillofacial surgery (("finite element analysis"[MeSH Terms] OR ("finite"[All Fields] AND “element”[All Fields] AND "analysis"[All Fields]) OR "finite element analysis"[All Fields]) AND ("surgery, oral"[MeSH Terms] OR ("surgery"[All Fields] AND "oral"[All Fields]) OR “oral surgery”[All Fields] OR ("maxillofacial”[All Fields] AND 
“surgery”[All Fields]) OR “maxillofacial surgery”[All Fields])) NOT plates[All Fields] AND ("humans"[MeSH Terms] AND English[lang] AND “2008/06/26”[PDat] : “2011/06/25”[PDat]) with 40 articles found, 36 articles excluded, and 4 articles selected;

2.- haptic AND maxillofacial surgery (haptic[All Fields] AND ("surgery, oral"[MeSH Terms] OR ("surgery"[All Fields] AND “oral"[All Fields]) OR “oral surgery”[All Fields] OR (“maxillofacial”[All Fields] AND “surgery”[All Fields]) OR "maxillofacial surgery"[All Fields])) AND ("humans"[MeSH Terms] AND English[lang] AND “2008/06/26”[PDat] : “2011/06/25”[PDat]) with 4 articles found, 3 articles excluded, and 1 article selected;

3. computer-assisted surgery AND maxillofacial surgery (computer-assisted[All Fields] AND "planning”[All Fields] AND ("surgery, oral”[MeSH Terms] OR ("surgery”[All Fields] AND “oral”[All Fields]) OR "oral surgery”[All Fields] OR ("maxillofacial”[All Fields] AND “surgery"[All Fields]) OR "maxillofacial surgery”[All Fields])) AND ("humans"[MeSH Terms] AND English[lang] AND “2008/06/26”[PDat] : “2011/06/25”[PDat]) with 120 articles found, 111 articles excluded or duplicated, and 9 articles selected;

4. computer-assisted navigation AND maxillofacial surgery computerassisted[All Fields] AND navigation[All Fields] AND ("surgery, oral”[MeSH Terms] OR ("surgery"[All Fields] AND "oral”[All Fields]) OR “oral surgery"[All Fields] OR ("maxillofacial"[All Fields] AND "surgery"[All Fields]) OR "maxillofacial surgery"[All Fields])) AND ("humans"[MeSH Terms] AND English[lang] AND “2008/06/26”[PDat] : “2011/06/25”[PDat]) with 42 articles found, 26 excluded or duplicated, and 16 articles selected;

5. distraction osteogenesis AND maxillofacial surgery (("osteogenesis, distraction"[MeSH Terms] OR (“osteogenesis"[All Fields] AND “distraction"[All Fields]) OR “distraction osteogenesis”[All Fields] OR (“distraction”[All Fields] AND “osteogenesis”[All Fields])) AND (“technology”[MeSH Terms] OR “technology”[All Fields]) AND (“surgery, oral"[MeSH Terms] OR ("surgery"[All Fields] AND “oral"[All Fields]) OR “oral surgery”[All Fields] OR (“maxillofacial”[All Fields] AND “surgery”[All Fields]) OR "maxillofacial surgery"[All Fields])) AND ("humans"[MeSH Terms] AND English[lang]), with 40 articles found, 31 excluded or duplicated, and 9 articles selected;

6. maxillofacial surgery AND robot (("surgery, oral"[MeSH Terms] OR ("surgery”[All Fields] AND “oral”[All Fields]) OR “oral surgery”[All Fields] OR ("maxillofacial”[All Fields] AND "surgery"[All Fields]) OR "maxillofacial surgery"[All Fields]) AND robot[All Fields]) AND (English[lang] AND “2001/07/15”[PDat] : “2011/07/12”[PDat]) 41 articles found, 41 excluded or duplicated;

7. minimal invasive surgery AND maxillofacial surgery minimal[All Fields] AND invasive[All Fields] AND ("surgery, oral"[MeSH Terms] OR ("surgery”[All Fields] AND “oral”[All Fields]) OR "oral surgery”[All Fields] OR ("maxillofacial"[All Fields] AND “surgery"[All Fields]) OR "maxillofacial surgery"[All Fields])) AND ("humans"[MeSH Terms] AND 
English[lang] AND “2008/06/27”[PDat] : “2011/06/26”[PDat]) with 37 articles found, 34 articles excluded, and 3 articles selected.

Five of the seven specific formulas had a limit of time (3 years) and of language (English). One specific formula (robot AND maxillofacial surgery) was limited to 10 years (and to the English language) because of the low number of articles on this topic during the last 3 years. One formula had no limit of time (distraction osteogenesis) because there were very few articles searchable in that group. To complete the research, 96 more articles were added after selection by hand search from the US Patent Office, the European Patent Office, subject related books, and the following journals: International Journal of Computer Assisted Radiology and Surgery, Revue de Stomatologie et de Chirurgie Maxillo-faciale, American Journal of Orthodontics, Journal of Oral and Maxillofacial Surgery, Journal of Cranio-maxillofacial Surgery, European Journal of Orthodontics, American Journal of Orthodontics and Dentofacial Orthopedics, International Journal of Oral and Maxillofacial Surgery, Journal of Clinical Orthodontics, Neuroradiology, Computer Aided Surgery, International Journal of Adult Orthodontics and Orthognathic Surgery, Studies in Health Technology and Informatics, Archives of Surgery, International Journal of Oral and Maxillofacial Implants, Clinical Implant Dentistry and Related Research, Periodontology 2000, Journal of Prosthetic Dentistry, Oral Surgery, Oral Medicine, Oral Pathology, Oral Radiology, and Endodontology, Medical Physics, British Journal of Oral and Maxillofacial Surgery, Clinical Oral Implants Research, and Journal of Orofacial Orthopedics. Altogether, we found 1721 articles. Most of the articles (1428) were excluded based on the title and abstract and because of duplications between the nine search formulas. Finally, 292 articles were selected for the present review.

\section{RESULTS}

The 292 articles selected were classified into the following groups: finite element analysis $(n=18)$, computer-assisted surgery $(n=111)$, rapid prototyping models $(n=$ $41)$, preoperative training simulators $(n=4)$, surgical guides $(n=23)$, image-guided navigation $(n=58)$, augmented reality $(n=2)$, video tracking $(n=1)$, distraction osteogenesis $(n=19)$, robotics $(n=8)$, and minimal invasive surgery $(n=7)$.

\section{DISCUSSION}

\subsection{Preoperative Planning}

\subsubsection{Finite Element Analysis in CMF Surgery}

A 3D finite element (3D FE) model of the face can be based on bones, muscles [1], skin, fat, and superficial musculoaponeurotic system reconstructed from MRI, and modeled according to anatomical, plastic, and reconstructive surgery literature [2, 3]. The FE mesh, composed of hexahedron elements, is generated through a semi-automatic procedure with an effective compromise between the detailed representation of the anatomical parts and the limitation of the computational time [2]. Nonlinear constitutive equations can be implemented in the FE model [2]. The corresponding model parameters are selected according to mechanical measurements on soft facial tissue, or are based on reasonable assumptions [2]. Model assumptions concerning tissue geometry, interactions, mechanical properties, and the boundary conditions can be 
validated through comparison with experiments [2]. The calculated response of facial tissues to gravity loads, to the application of pressure inside the oral cavity and to the application of an imposed displacement shows good agreement with the data from the corresponding MRI and holographic measurements [2]. The goal of the FE models of the face in CMF surgery is to predict the postoperative facial appearance with respect to prespecified bone-remodeling plans [3], and to predict the aging process [2]. Moreover, biomechanical analysis based on FE analysis (FEA) was proposed to better understand the biomechanical mechanism of rapid maxillary expansion, which is used in modifying the shape of the maxilla in cleft palate patients [4]. In CMF traumatology, biomechanical analyses involving FEA [5] were proposed to understand the role of osteosynthesis fixation $[6,7]$ and to find the best possible treatment (miniplates, screws, bioresorbable plates) for different fractured sites in the CMF skeleton such as mandibular symphysis [8], mandibular angle fracture [9], orbital fractures [10, 11], and massive midface injuries with bone loss [12]. FEA could also prove useful in the future to predict the likelihood of iatrogenic fracture of the jaws after surgical removal of mandibular bone, such as that occurs when the third molar is removed, and this may allow surgeons to change their approach to tooth removal in certain cases [13]. In implantology, FEA was used to choose the best drilling technique in relation to the type of bone $[14,15]$. The results of the FEA imply that the success of a sinus-augmented dental implant is heavily dependent on the implant design and the rigidity of the bone grafts [15]. Presurgical FEA was also developed to predict the motion of the craniofacial skeleton under different constraints due to different types of distractors and different spatial vectors $[16,17]$. Finally, FEA was used to determine the optimum consolidation period for implant loading under forces of different directions and amounts after alveolar distraction osteogenesis [18].

\subsubsection{Computer Assisted Surgery Planning}

Computer-assisted surgery (CAS) planning was implemented in CMF surgery so that the complex anatomy of the patient can be understood, and that the surgical task can be improved preoperatively [19-25]. Orthognathic surgery represents an important part of CMF surgery and allows for correction of different dental and maxillofacial dysmorphoses, asymmetric faces, or craniofacial syndromes by cutting and moving the maxilla and/or the mandible according to a treatment plan. Standard orthognathic surgery planning is shown in Figure 1. This procedure can be divided into the following four steps [26, 27]:

- "A"- Clinical examination, diagnosis and treatment planning.

- "B" - Transfer of maxillary and mandibular initial position to the articulator.

- "C" - Model surgery.

- "D" - Transfer of final relative maxillary-mandibular position to the operating room (OR).

In the current system, none of these steps require computer assistance. After the clinical examination [28] (Fig 1.1 - "A1"), standard orthognathic preoperative planning begins with diagnosis and treatment planning ("A2"). The diagnosis is achieved using a two-dimensional (2D) cephalometric analysis ("A2"). The treatment is generated by associating data from the clinical examination (aesthetic aspects, gingival smile, etc), 
and the occlusal examination (on plaster casts), with results from the 2D cephalometric analysis. 2D cephalometric analysis provides measurements of the maxillary and/or mandibular movements to perform during model surgery ("C") and the operative time in relation to existing normative data or to the individual's geometrical frame [29]. Registration of the maxillary position in relation to the skull is achieved by using a face bow ("B1") [30]. Registration of the mandibular position in relation to the maxilla is obtained by using an occlusal wax bite positioned between the two dental arches ("B2"). The face bow is then placed in a semi-adjustable articulator ("C1"). The face bow transfers the 3D position of the maxilla into a semi-adjustable articulator [31]. A plaster cast of the maxilla is positioned on the face bow ("C2") and fixed by plaster to the upper arm of the articulator. The occlusal bite registration is used for positioning the mandibular plaster cast relative to the maxilla. Horizontal and vertical reference lines are traced for both plaster casts ("C3"). The plaster casts are then separated from the articulator by sawing. The casts are subsequently moved by the surgeon to their final positions ("C4, c"). The amount of movement imposed to the plaster casts should theoretically correspond to that planned with the $2 \mathrm{D}$ cephalometric analysis. This movement may create a gap between the reference lines. The gap is measured with a manual caliper [32]. The intercuspidation plate (or splint) ("D") represents the impression (in resin) of teeth contacts between the two dental arches. The intermediary and final maxillary positioning in relation to the mandibular plaster cast requires the manufacturing of two splints [33-35], which represent the unique element of transfer between model surgery (“C4") and OR (“D”).

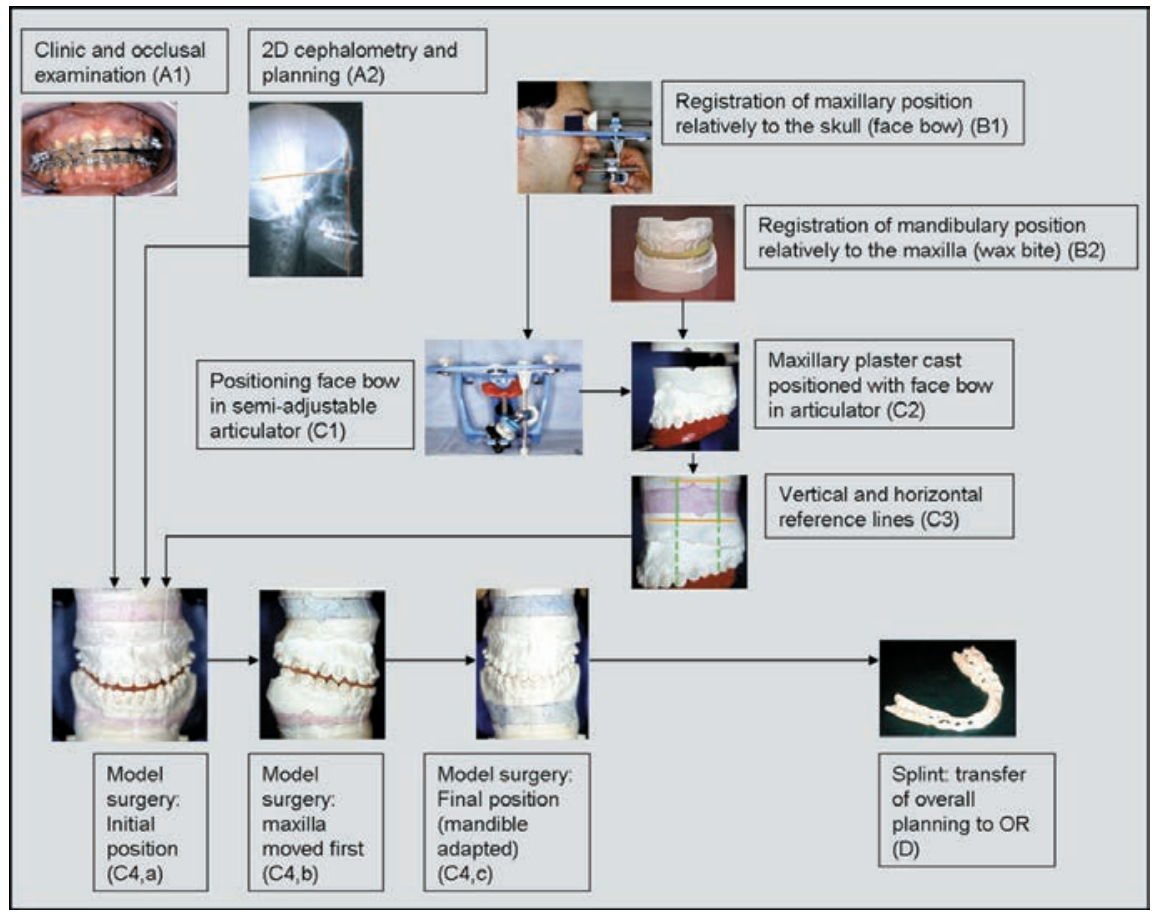

Figure 1. Standard orthognathic surgery planning. 
Table 1. The pitfalls and limitations of a standard orthognathic surgical procedure.

\begin{tabular}{|l|l|l|l|}
\hline $\begin{array}{l}\text { 2D radiological } \\
\text { planning (A2) } \\
{[29,36-40]}\end{array}$ & $\begin{array}{l}\text { Face-bow (B1) [26, } \\
30,31,40]\end{array}$ & $\begin{array}{l}\text { Model surgery (C2-C4) } \\
{[26,40-44]}\end{array}$ & Splint (D) [33, 40] \\
\hline $\begin{array}{l}\text { Insufficient distance } \\
\text { between the source } \\
\text { and the target }\end{array}$ & $\begin{array}{l}\text { Inaccuracy in the 3D } \\
\text { positioning of the } \\
\text { device }\end{array}$ & Hand-drawn reference lines & $\begin{array}{l}\text { Resin may be deformed if } \\
\text { heating is not achieved within } \\
\text { the articulator }\end{array}$ \\
\hline $\begin{array}{l}\text { Inadequate filter } \\
\text { application }\end{array}$ & $\begin{array}{l}\text { Two clinicians } \\
\text { required for } \\
\text { manipulation }\end{array}$ & $\begin{array}{l}\text { No standards for horizontal } \\
\text { or vertical reference lines }\end{array}$ & $\begin{array}{l}\text { High risk of destruction of the } \\
\text { occlusal part of the models } \\
\text { when resin is not correctly } \\
\text { separated from the plaster casts }\end{array}$ \\
\hline $\begin{array}{l}\text { Superimpositions of } \\
\text { anatomical } \\
\text { structures }\end{array}$ & $\begin{array}{l}\text { Long time for } \\
\text { manipulation }\end{array}$ & $\begin{array}{l}\text { The reference lines do not } \\
\text { correspond to any lines from } \\
\text { the 2D cephalometry }\end{array}$ & $\begin{array}{l}\text { Splint does not transfer any } \\
\text { absolute position of the maxilla } \\
\text { and/or mandible in relation to } \\
\text { the skull }\end{array}$ \\
\hline $\begin{array}{l}\text { Impossible to } \\
\text { quantify right-left } \\
\text { asymmetry }\end{array}$ & $\begin{array}{l}\text { The reference lines do not } \\
\text { correspond to any of the } \\
\text { osteotomy lines }\end{array}$ & $\begin{array}{l}\text { No standard for movement } \\
\text { (translation or rotation) to } \\
\text { perform first during } \\
\text { manipulations of the plaster } \\
\text { casts }\end{array}$ & $\begin{array}{l}\text { No quantifiable control } \\
\text { during the rotations of the } \\
\text { plaster casts }\end{array}$ \\
\hline & &
\end{tabular}

CAS [45] was introduced in orthognathic surgery as one of the technologies (Table 2) to resolve multiple weaknesses and pitfalls of standard procedures (Table 1) [46]. The stages of the CAS workflow process for routine 3D virtual treatment planning of orthognathic surgery are the following: (1) image acquisition for 3D virtual orthognathic surgery, (2) processing of the acquired image data to construct a 3D virtual augmented model of the patient's head [47], (3) 3D virtual diagnosis of the patient [48], (4) 3D virtual treatment planning for the orthognathic surgery, (5) 3D virtual treatment planning communication, (6) 3D splint manufacturing, (7) 3D virtual treatment planning transfer to the OR, and (8) 3D virtual treatment outcome evaluation [49]. The image acquisition and processing of data for the $3 \mathrm{D}$ virtual treatment planning can merge information from bone (computed tomography (CT) scan, cone beam CT) [50, 51], soft tissues [24, 52], external facial appearance [53-59], 3D photographic system [57], and dental occlusion [47, 60-63] to provide the most complete 3D virtual model of each patient [64]. Figure 2 exhibits an example of CAS planning in orthognathic surgery. 


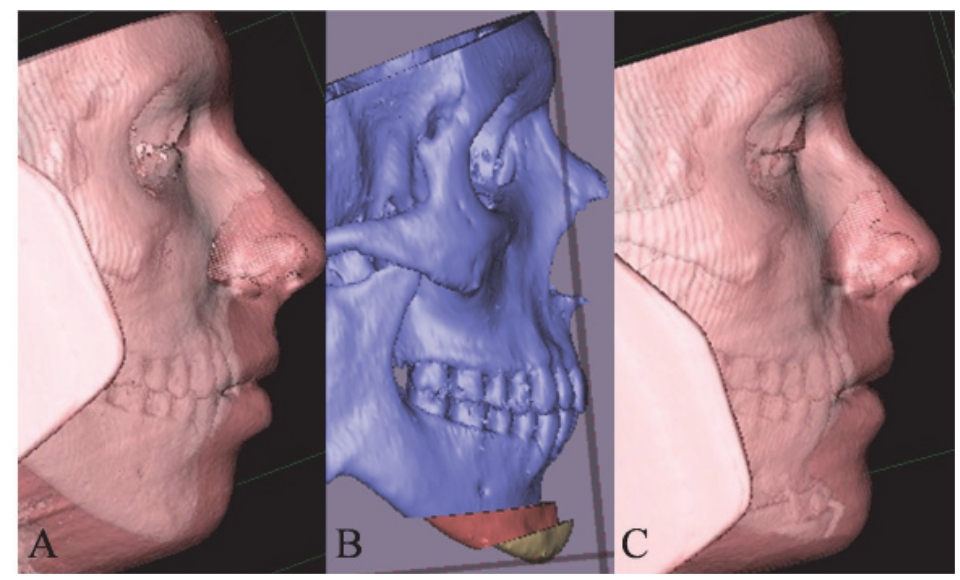

Figure 2. CAS planning in orthognathic surgery. (A) Pre-operative profile with soft and hard tissue superimposition. (B) Virtual planning with 3D cephalometric analysis and double advancement of the chin. (C) Postoperative visualisation of soft and hard tissues modification.

Table 2. Different technologies used in orthognathic surgery for the analysis, planning, and transfer of preoperative planning to $\mathrm{OR}$.

\begin{tabular}{|c|c|c|c|c|c|c|}
\hline Task & \multicolumn{6}{|c|}{ Means } \\
\hline Analyze & $\begin{array}{l}\text { 2D X-Rays } \\
\text { manual } \\
\text { cephalometry } \\
{[72-81]}\end{array}$ & $\begin{array}{l}\text { 2D X-Rays } \\
\text { digital } \\
\text { cephalometry } \\
{[82]}\end{array}$ & & $\begin{array}{l}\text { 3D cephalometry } \\
\text { CT }[83-86]\end{array}$ & & \\
\hline $\begin{array}{l}\text { Simulate } \\
\text { bone } \\
\text { movements }\end{array}$ & $\begin{array}{l}\text { Articulator and } \\
\text { plaster casts }[72, \\
87-91]\end{array}$ & $\begin{array}{l}\text { Robot arm for } \\
\text { model surgery } \\
\text { [92] }\end{array}$ & $\begin{array}{l}\text { 3D RP } \\
\text { model } \\
{[73,93]}\end{array}$ & $\begin{array}{l}\text { CAS planning } \\
{[84,85,94-98]}\end{array}$ & & \\
\hline $\begin{array}{l}\text { Simulate soft } \\
\text { tissues }\end{array}$ & & & & $\begin{array}{l}\text { CAS planning (CT, } \\
\text { laser scan) } \\
\text { [99-102] }\end{array}$ & & \\
\hline $\begin{array}{l}\text { Check } \\
\text { occlusion }\end{array}$ & $\begin{array}{l}\text { Plaster casts [72, } \\
84,85,87,92]\end{array}$ & & $\begin{array}{l}3 \mathrm{D} \mathrm{CT} \\
\text { reconstr- } \\
\text { uction } \\
{[63]}\end{array}$ & $\begin{array}{l}\text { Laser scanned } \\
\text { virtual model [82] }\end{array}$ & $\begin{array}{l}\text { Combinat- } \\
\text { ion 3D CT } \\
\text { - laser scan } \\
\text { virtual } \\
\text { model } \\
{[103]}\end{array}$ & \\
\hline Transfer & $\begin{array}{l}\text { Acrylic splint } \\
{[72]}\end{array}$ & & $\begin{array}{l}\text { Surgical } \\
\text { guide } \\
{[73,85]}\end{array}$ & $\begin{array}{l}\text { Image-guided } \\
\text { surgery [82, 84, } \\
104-107]\end{array}$ & $\begin{array}{l}\text { Augmented } \\
\text { reality } \\
{[108]}\end{array}$ & $\begin{array}{l}\text { Robotics } \\
{[92,109,110]}\end{array}$ \\
\hline
\end{tabular}


Three-dimensional virtual diagnosis and treatment planning enable us to simulate and quantify osteotomies [65] and bone movements, to try to predict postoperative soft tissues appearance with a photorealistic quality $[66,67]$, and to verify the achievement of good postoperative virtual dental occlusion by means of collision detection algorithms $[63,68]$. The movements of the mandible can be added to the $3 \mathrm{D}$ virtual model of the patient to provide dynamic/functional data and to predict surgical outcomes $[69,70]$. In 3D virtual planning, a precise knowledge of the location of the mid-facial plane is important for the assessment of asymmetric deformities and for the planning of reconstructive procedures [69]. Automatic extraction of the mid-facial plane was proposed by De Momi et al. [71] based on matching homologous surface areas selected by the user on the left and right facial sides through iterative closest point optimization. Soft tissue prediction of the patient's final appearance after orthognathic surgery still needs some improvements [66, 67].

CAS planning in implantology allows obtaining highly precise implant positioning, taking advantage of the maximum amount of bone available, and facilitating minimally invasive surgery [111]. The workflow consists of the following steps: (1) CT/cone beam CT data acquisition [112], (2) 3D reconstruction, and (3) 3D implant planning (Implametric, Simplant [113], NobelGuide [115, 116], med 3D [117, 118]). These software allows for axial cuts and panoramic cuts with multiple bucolingual cuts. Bony and soft tissues structures can be easily visualized [114]. The tendency is toward prosthodontic-driven implant placement (Figure 3), taking into account the later prosthetic restoration [111], and to achieve integration of anatomical, biomechanical, and aesthetic factors [119]. To incorporate the information from the prosthodontic waxup, a template is prepared and introduced into the workflow. First, a template with radioopaque position markers (gutta-percha or calibrated balls of known diameter) or a special radioopaque template (with barium sulfate coating) is made for the patient [114, 120] (Figure 3). Then the patient without the template and the template itself are separately CT scanned (Nobel guide procedure). Using the chosen software, a treatment is planned based on the implant position in the axial, sagittal and panoramic sections. The functional and aesthetic outcome will be satisfactory if the template is made based on the final shape of the tooth (shape, emergency profile, occlusion, and contact areas) and not based on bone quality alone [113]. The template can also be modified to serve as a surgical guide. If the modification of tamplate is not possible, a new surgical guide is manufactured [113]. A different template can be used for a different supporting surface. The templates can be supported by teeth or both teeth and mucosa, or they can be directly fixed to the maxilla bone $[114,121]$. The template can be stabilized by placing pins directly into the bone through soft tissue [114], raising a flap and placing the template into the bone, using wires as a guide and support [113], using transitional implants [122], or placing the template over soft tissues [114, 120]. 3D CT reconstruction enables determining the implant number, location, angle and characteristics [114]. CAS in implantology is appropriate for situations with anatomical limitations, such as an inferior alveolar nerve [120], nasal fossae or maxillary sinus [117, 123], or atrophic maxilla [119]. CAS allows visualization of the amount of available bone in each area, which is important for choosing the ideal donor site for the osseous grafts. CAS also enables choosing the best graft location as well as the shape and volume of the graft $[119,123]$. In complex procedures, such as zygomatic implants 
[124], 3D CAS implantology planning helps to follow the critical anatomical structures along the implant trajectory $[125,126]$.

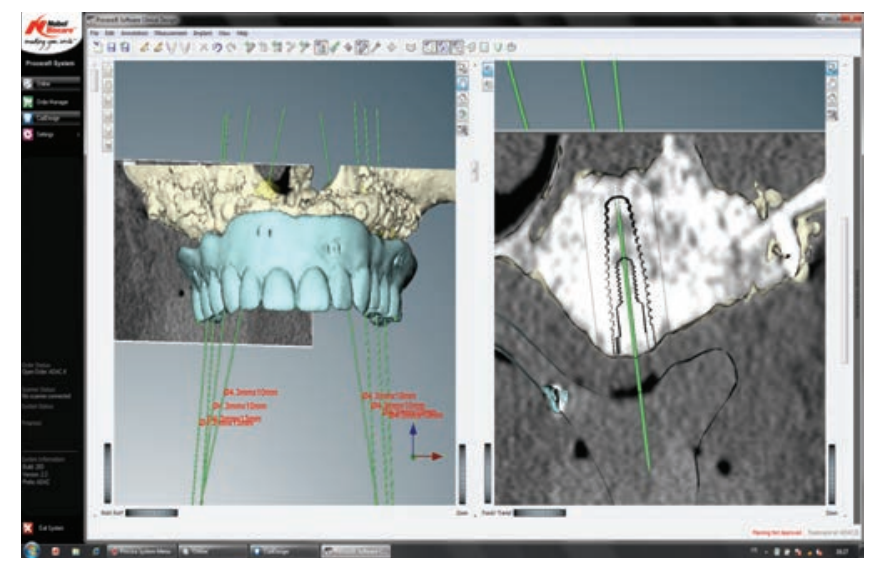

Figure 3. CAS planning in implantology. Virtual planning of 8 implants positioning in the upper maxilla after a double sinus lift, with the help of the prosthodontic-driven template (in blue).

In reconstructive oncological CMF surgery, virtual bending of the mandibular reconstructive plate [127] or shaping of the fibular graft to reconstruct the mandible after oncological resectioning can be performed by means of computer-aided design/computer-aided manufacturing (CAD/CAM) procedures [128]. CAS planning has also been used for the evaluation of the presurgical mandibular anatomy, by which 3D models of the fibula graft are obtained [128, 129].

\subsubsection{Rapid Prototyping 3D Models}

Rapid prototyping (RP) was introduced in the 1980's as a techniques for manufacturing of physical models from CAD/-CAM. In RP, a medical model is built layer by layer, reproducing almost every shape of the external and the internal anatomical structures (Table 3). RP models are different from the physical models manufactured by drilling [130]. The medical models or bio-models represent a part of the human anatomy at a 1:1 scale obtained from 3D medical imaging (CT scan, MRI). Fabrication of the medical models consists of four main steps: (1) 3D imaging (3D CT, MRI), (2) image processing including segmentation of the zone of interest, (3) image data optimization, and (4) construction of the medical model with RP.

Different methods have been proposed, such as stereolithography [131-135], selective laser sintering (SLS) [136, 137], PolyJet [138], fused deposition modeling [139], and 3D printing [140] (Table 3). Artifacts in 3D RP models are due to data import, computed tomography gantry distortion, metal, motion, surface roughness due to removal of support structure or surface modeling, and image data thresholding [139]. The source of the artifact can be related to the patient, to the imaging modality performance, or to the modeling technology [139]. RP medical modeling in CMF surgery involves multiple indications for diagnosis [143], instruction for residents [133], and patient information 
tool when obtaining consent for surgery [134]. A specific application of RP technology is the diagnosis and treatment planning for facial fractures (i.e., titanium mesh prebent on 3D RP models to correct orbital fractures) (Figures 4, 5) [144-148].

Table 3. Different techniques of RP modeling for craniomaxillofacial surgery

\begin{tabular}{|c|c|c|}
\hline Name & $\begin{array}{l}\text { Technical } \\
\text { principle }\end{array}$ & Dimensional error \\
\hline Stereolithography & $\begin{array}{l}\text { Photopolymer } \\
\text { cured layer by layer } \\
\text { with UV laser }\end{array}$ & $2.2 \%[141]$ to $2.7 \%[142]$ \\
\hline $\begin{array}{l}\text { Selective laser } \\
\text { sintering }\end{array}$ & $\begin{array}{l}\mathrm{CO}_{2} \text { laser beam } \\
\text { heats powder } \\
\text { particles and fuses } \\
\text { them together }\end{array}$ & $1.79 \%[138]$ to $2.1 \%[136,138]$ \\
\hline $\begin{array}{l}\text { Fused deposition } \\
\text { modeling }\end{array}$ & $\begin{array}{l}\text { Extrusion of heated } \\
\text { thermoplastic } \\
\text { material layer by } \\
\text { layer }\end{array}$ & Not found \\
\hline Polyjet & $\begin{array}{l}\text { Jetting a state-of- } \\
\text { the-art } \\
\text { photopolymer in } \\
\text { ultrathin layers } \\
\text { (16 } \square \mathrm{m} \text { ) onto a build } \\
\text { tray }\end{array}$ & $2.14 \%[138]$ \\
\hline 3D printing & $\begin{array}{l}\text { Selective dispersion } \\
\text { of binder onto } \\
\text { powder layers }\end{array}$ & $3.14 \%[138]$ \\
\hline
\end{tabular}

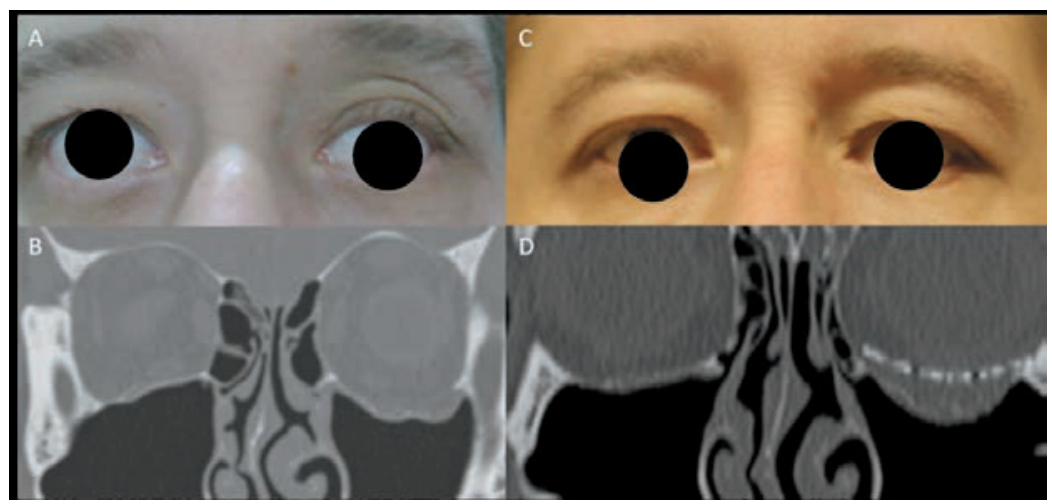

Figure 4. Rapid prototyping (RP) applied to the diagnosis and treatment planning for orbital fractures. (A) Pre-operative soft-tissue appearance for late left inferior orbital wall fracture with enophthalmos and accentuated upper palpebral fold on the left side. (B) Preoperative low-dose CT scan, coronal view, fracture of the left orbit floor. (C) Postoperative appearance of left eye; correction of the left palpebral fold. (D) Postoperative lowdose CT scan, coronal view, restoratio ad integrum of the left inferior orbital wall with the pre-shaped titanium mesh. 


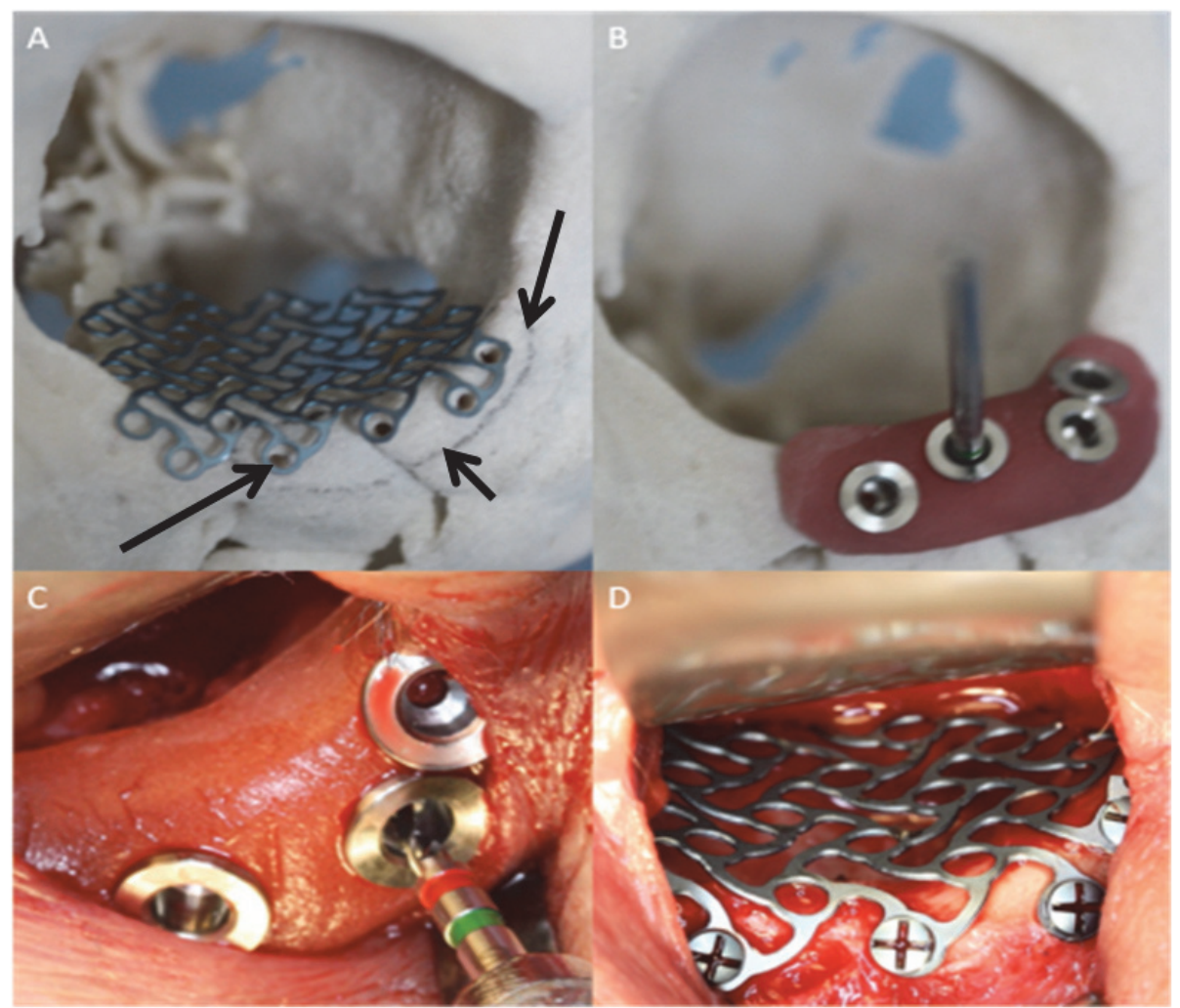

Figure 5. Rapid prototyping (RP) applied to the surgery for orbital fractures (same patient as in Figure 4). (A) Pre-bent titanium mesh on the 3D RP model. The holes for the screws and the size of the guide are marked with black pencil (arrow). (B) The acrylic surgical guide for the positioning of the holes for the screws on the 3D RP model; positioning of the drill at $90^{\circ}$ to the bone surface. (C) Intra-operative drilling of the holes through the surgical guide. (D) Intra-operative view of the positioning of the pre-bent titanium mesh on the left orbital floor.

RP models afford manufacturing of surgical guides and splints [149] for transfer of preoperative planning (osteotomy lines, bone movements, facial asymmetry) to the operating theater in orthognathic surgery [150-152], implantology [153], and distraction osteogenesis [154-155]. In reconstructive oncological CMF surgery, 3D RP models of the fibula graft allow for choosing the best titanium plates, allow for the bending of the plates preoperatively (reducing the time spent in the operating theater [156]), and help in preoperatively planning the osteotomies and bone movements [156160]. The 3D RP models also serve for prosthetic implant design in cranioplasty [161$166]$, prosthodontic rehabilitation of the midface after malignant tumor resection [167, $168]$ and the preparation for temporomandibular joint replacement $[169,170]$. 


\subsubsection{Preoperative Training}

Very few simulators have been developed for CMF surgery, except the physical [171] or virtual [172] simulators for facial cleft palate repair and mandibular reconstruction [173]. Haptic models were added to simulate routine oral surgery procedures, such as bone drilling [174].

\subsection{Intraoperative Guidance}

\subsubsection{Surgical Guides}

In orthognathic surgery, virtual planning can be transferred to the OR with a surgical occlusal splint prepared by CAD-CAM procedures [175-177]. Olszewski et al. [178] proposed using an acrylic guide based on a 3D RP printed model for the transfer of the osteotomy lines and the screw holes for the osteosynthesis titanium plates from the preoperative orthognathic surgery planning (genioplasty) to the operating theater (Figures 6-8).

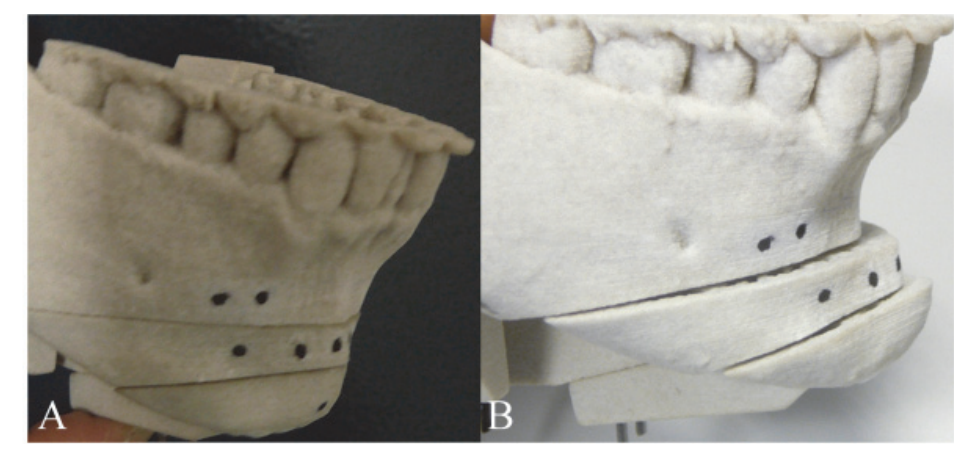

Figure 6. Surgical guide based on 3D RP printed model for the transfer from the preoperative orthognathic surgery planning to the operating theater. (A) 3D RP model, pre-operative initial position. (B) 3D RP model, postoperative final position. Black dots indicate the position of holes for the screws [178].

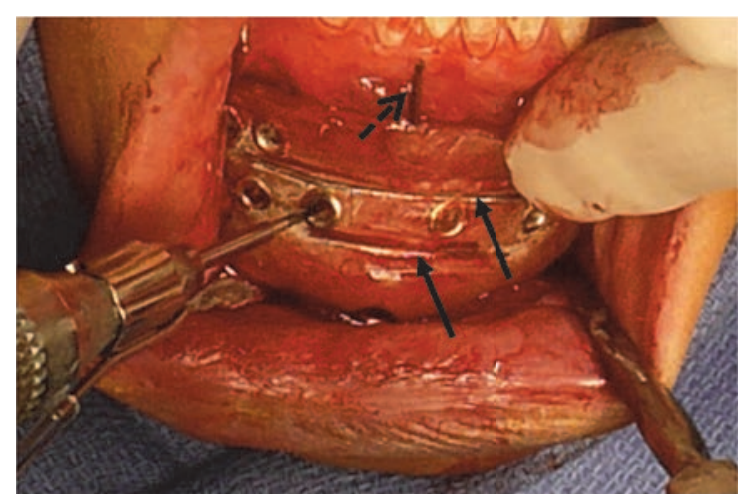

Figure 7. The acrylic guide is positioned on the osseous chin of the patient. The holes for the screws are drilled through the surgical guide. Solid arrows indicate the transfer lines for osteotomy paths. The broken arrow marks the midline indicator of the acrylic guide. The acrylic guide is fabricated on the 3D RP model based on the initial position [178]. 


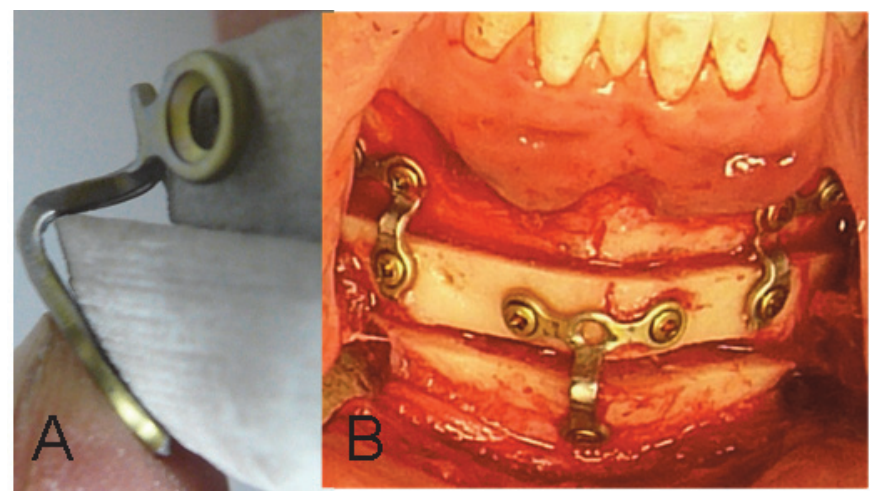

Figure 8. (A) Prebent plate on the $3 \mathrm{D}$ RP model in the final position. (B) Positioning and screwing of the pre-bent plates intraoperatively [178].

For CMF skull reconstruction, Clijmans et al. [179] described thin metallic templates to transfer preoperative planning of the new shape of the dysmorphic skull to the OR. In reconstructive CMF surgery, a surgical guide based on a 3D RP model is used for resectioning of the fibula and for its insertion into the resected defect on the mandible $[158-160,180,181]$. The length of the resected mandibular bone, the mandibular curvature, and the width of the basal bone can also be transferred to the fibula flap with a surgical guide [158].

In CAS implantology [191, 194], surgical guides are used to facilitate procedures such as maxillary sinus lift elevation (bone grafting of the maxillary sinus before implant placement in the maxilla) (Figure 3) [195], zygomatic implants [124] or pterygoid implant positioning [196], and placement of orbit prosthesis after orbital exenteration [197]. The advantages and disadvantages of surgical guides in implantology are summarized in Table 4.

\subsubsection{Image-Guided Navigation}

Image-guided navigation leads to an improvement in surgical accuracy with the aid of software that uses the images captured from CT or MRI and a tracking system for the surgical instruments [126]. The accuracy of image-guided navigation in CMF [198]

Table 4. The advantages and disadvantages of surgical guides in implantology.

\begin{tabular}{|l|l|}
\hline Advantages & Disadvantages \\
\hline $\begin{array}{l}\text { Transfer of the diagnostic wax-up for a prosthodontic } \\
\text { restoration into actual implant planning [182] }\end{array}$ & Not allowed for alveolar ridge expansion [126] \\
\hline Increased precision of implant positioning [113,183] & Conditions of mucosa not considered [184] \\
\hline Increased directional precision of drilling [185, 187] & Tactile reference lost [189] \\
\hline Reduced operating time [113,188] & Precise milling depth not given [126] \\
\hline Reduced surgical errors [113,190] & Bone interference [193] \\
\hline Bone and tooth support possible [114, 191, 192] & \\
\hline
\end{tabular}


depends on the imaging modalities [199], patient-to-image registration procedures, the navigation system used [200-202], data acquisition [94], interaction of the surgeon with the system [200], technical errors [200], and instrument tracking [203-205]. The technical accuracy and the navigation procedures seem to be of minor influence [198].

Image-guided navigation requires a means of registering anatomical points in the medical image (CT or MRI) and a software program to locate the surgical instruments [198, 206-210]. Knowing the exact position of the instrument is the key to the success of the surgical intervention. CT/MRI images are used as a map to provide the surgeon with a real-time representation of the surgical instruments in relation to the images of the patient. This real time representation allows for tracking the instrument position during the surgery and their visualization on the computer [211]. During the surgical phase, the surgeon is given interactive support with guidance in order to better control potential dangers and avoid complex anatomical regions [94, 212]. Navigation is possible through a series of sensors attached to the rotator instruments, the surgical template and a cap fixed on the patient's head, and the data are captured by different systems. The obtained data are transferred immediately to the computer and enable the surgeon to view the real situation [94].

The systems used in image-guided navigation evolved from stereotactic neurosurgical systems (mechanical) [94, 211], ultrasound-based (connected to satellite) [94], and electromagnetic systems (based on the localization of the instruments by measuring the changes produced in the magnetic field intensity) [211, 212], to optical navigation systems based on infrared light (localization of infrared light emitting diodes on the instruments captured through cameras mounted in the operation room) [211, 213215]. StealthStation is the most accurate optical navigation system (mean [SD] target registration error: $1.00[0.04] \mathrm{mm})$, followed by VectorVision $(1.13[0.05] \mathrm{mm})$, and then Voxim $(1.34$ [0.04] mm $)(\mathrm{P}<.05)$ [202].

Traumatic CMF injuries often present difficult reconstructive challenges for CMF surgeons [216, 217]. Reconstruction is often complicated by significant soft tissue loss, comminuted bone fragments, tenuous blood supply, and wound contamination [217]. For panfacial injuries, restoration of normal facial width, facial height, and sagittal projection may be difficult to achieve [217]. Marked swelling may limit the surgeon's ability to palpate and recognize subtle bony defects and malunion [217]. Furthermore, a true 3D assessment of bony alignment may not be possible with traditional surgical exposures to the craniofacial skeleton [217]. Image-guided navigation affords precise treatment of old fractured zygoma in the appropriate position and orientation [218, 219]. Intraoperative navigation can reconstruct a complex post-traumatic orbital anatomy, restore the midfacial symmetry and optimize the treatment outcome [220-222].

The association of CAS with stereolithographic models and with intraoperative navigation was applied to the planning and repair of zygomatico-orbito-maxillary complex fractures [223-225]. Intraoperative navigation in maxillofacial fracture repair facilitates reconstruction in unilateral defects through mirroring techniques, and reconstruction in bilateral defects by importing virtual models from standard CT datasets and by improving the software tools needed for maxillofacial surgical reconstruction [226-228]. 
Navigation can make tumor surgery more reliable by specifying the correct safety margins, protecting vital structures, and facilitating the reconstruction process [229]. Image-guided navigation is especially useful in tumor resection involving complex anatomy areas modified by tumor growth [230-232] (such as the orbit), in the proximity of cerebral structures, and when cranial nerves could be injured [233, 234]. Imageguided navigation allows for the immediate reconstruction of the unilateral resected area with an autologous graft designed and positioned under navigation with a preoperative plan based on the mirrored healthy side [235]. CAS navigation in CMF tumor resection can also be combined with new imaging modalities, such as positron emission tomography [236, 237]. In this combination, the surgeon is simultaneously provided with anatomical and functional (metabolic) details. The resulting fused images offer improved localization of malignant lesions and improve the targeting of the biopsy, especially for small lesions [236]. Reisner et al. [238] proposed the integration of spectroscopy-based biosensors with an image-guided surgery system. Their system can simultaneously provide the surgeon with information about the diagnosis of the tissue and its 3D localization. This information could help to increase the safety during surgery for malignant tumor resections [238].

In implantology, the accuracy achieved with manual implantation is sufficient [200]. However, some situations exist where a very precise navigation-guided implantation [239] is required, such as those due to anatomical limitations (inferior alveolar canal, nasopalatine canal, maxillary sinus, pterygoid region), limited space, atrophic maxillae [240-246], sinus lift, and trans-zygomatic implants [200, 247, 248]. Image-guided navigation in orthognathic surgery enables transfer of individualized 3D virtual planning and drilled screws holes for plating the osteotomy lines [249] to improve the reproducibility of the preoperative simulation [250, 251]. Intraoperative navigation has also been used in the resection of the ankylotic bone in temporomandibular joint (TMJ) gap arthroplasty [252] and for TMJ arthroscopy using optoelectronic tracking technology [253, 254].

The most difficult clinical situations for image-guided navigation in the CMF region are related to edentulous patients and to the mandible [255]. In edentulous patients, the registration depends on the required level of accuracy, the prospective region for surgical navigation, and the status of the patient's prosthesis [255]. The mobility of the mandible makes it difficult to accurately synchronize with preoperative imaging data [233]. However, a teeth-mounted sensor frame and teeth-supported fiducial markers can afford more accurate navigation for surgery of the lower jaw [233].

\subsubsection{Augmented Reality}

Augmented reality provides the surgeon with real-time intraoperative information from preoperative planning by see-through glasses or video projectors to directly visualize the planning data in the surgeon's field of view [256]. Mischkowski et al. [257] introduced the augmented reality tool (X-Scope) based on the visual tracking of real anatomic structures in superposition with volume-rendered CT or MRI for controlling the intraoperative translocation of the maxilla. 


\subsubsection{Video-tracking}

Intra-operative facial nerve monitoring, which is imperative in facial nerve dissection (resection of parotid glands tumors), is based on electromyography and video-tracks the ipsilateral oral commissure displacement in relation to different levels of current administered to the nerve during surgical procedures [258].

\subsubsection{Distraction Osteogenesis}

Distraction osteogenesis (DO) consists of sectioning and elongating a bone at a specific rate with a distractor to create bone by osseous distraction (Figure 9). Different types of DO devices are described in Table 5. DO can reconstruct a deformed skull, a midface complex, a mandible or an alveolar ridge [259-261].

The main issue in DO is the accurate positioning of the distractor on the maxillofacial skeleton (mandible, maxilla, and cranium) [267] and the choice of the best suitable distraction vector for 3D moving and shaping of the newly created bone and soft tissues. CAS planning has been employed for individual positioning of the distractor, performing virtual osteotomies, visualizing the displacement of newly created bone in 3D space, and correcting facial asymmetries [264, 268]. Curvilinear distractors require more precise positioning and individualized patient planning based on CAS. Yeshwant et al. [269] proposed quantifying the 3D curvilinear movement to elongate the mandible by 4 parameters of movement: radius of curvature, elongation, pitch, and handedness (left- or right-turning helix). Based on these parameters, a distraction device was constructed to execute a computer-assisted plan for skeletal correction [269]. 3D CAS simulation and model surgery provide accurate orientation of the distraction vectors [131]. A combination of virtual surgical simulations and stereolithographic models can be validated as an effective method of preoperative planning for complicated maxillofacial surgery cases [170, 155, 259, 262, 270-274]. Moreover, preoperative bending of distractors on RP models [273] prevents significant loss of operation time. In $\mathrm{DO}$, the 3D positioning of pins and screws affects the global movement vector and eventually affects the treatment outcome (insufficient correction of symmetry, insufficient amount of movement performed through the device) [275].

Table 5. Different types of distraction osteogenesis devices

\begin{tabular}{|l|l|l|}
\hline Degree of freedom (DOF) & Intraoral & Extraoral \\
\hline 1 DOF & $\begin{array}{l}\text { Internal trans-sinusoidal maxillary } \\
\text { distractor [262], alveolar ridge } \\
\text { distractor (KLS Martin Track } \\
\text { distractor [263], smile distractor } \\
\text { Titamed (maxillary transverse } \\
\text { expansion), Zurich pediatric ramus } \\
\text { distractor (KLS Martin) }\end{array}$ & $\begin{array}{l}\text { Rigid external distractor (RED), } \\
\text { Mono-block distractor (KLS } \\
\text { Martin) }\end{array}$ \\
\hline 2 DOF & & \\
\hline 3 DOF & Multiaxis mandibular DO [265] & $\begin{array}{l}\text { Leibinger [266] } \\
\text { Medartis AG [264] }\end{array}$ \\
\hline
\end{tabular}


Therefore, Kofod et al. [275] proposed transferring vector planning from 3D RP models to the operating theater through a guiding splint, while Lübbers et al. [276, 277] introduced image-guided navigation for positioning the screws during fixation of the distractor. Without navigation, the mean deviation from the planned position was 4.9 $\mathrm{mm}$ (varying from 0.9 to $10.7 \mathrm{~mm}$ ), with a clear tendency to position the screws in the easy-to-access regions. With navigation, the mean deviation was significantly reduced to $1.5 \mathrm{~mm}$ (varying from 0.1 to $3.4 \mathrm{~mm}$ ).

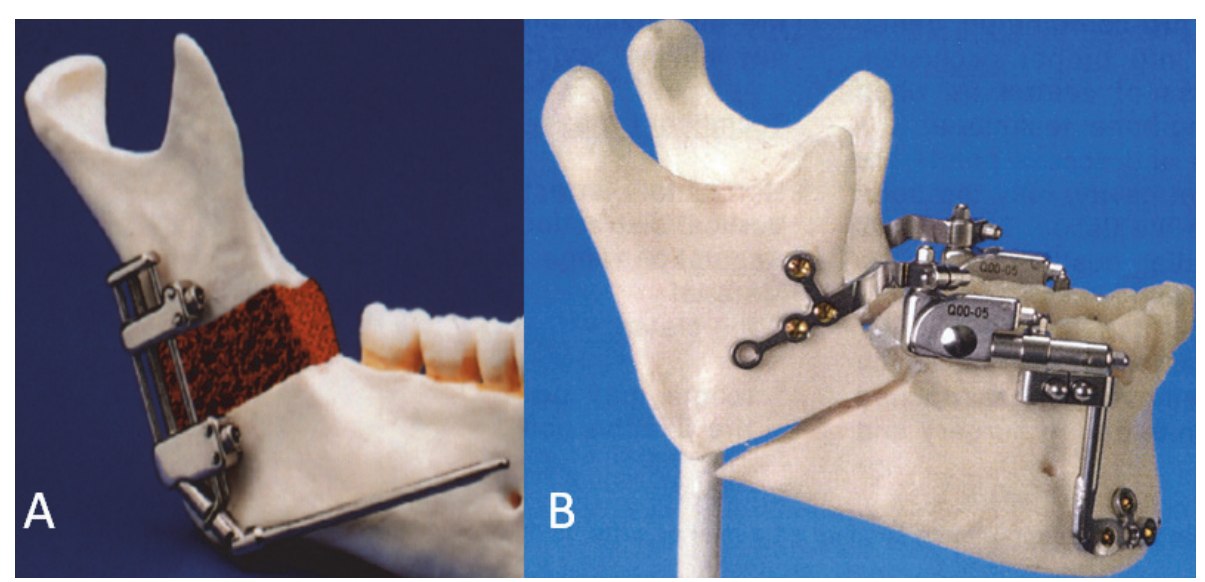

Figure 9. Internal distraction osteogenesis (DO) device with (A) 1 DOF for vertical ramus elongation, and (B) 3 DOF for horizontal ramus elongation [265].

\subsubsection{Robotics in $C M F$}

The use of robotics in CMF surgery is still limited to research institutions or large clinics, because it is difficult to implement the necessary technical and logistic measures in routine surgical work [110, 278]. The robotic system RoboDent can transfer the virtual preoperative plan for positioning the oral implants to the OR [279, 280]. This system is based on CAS navigation of the drilling system, control of the orientation of the drilling system in space, and control of the depth of drilling, through a computer-assisted interface. The absolute implant position accuracy was approximately $0.5 \pm 0.4 \mathrm{~mm}$, the relative accuracy between the implants was approximately $0.2 \pm 0.5 \mathrm{~mm}$, and the deviation from the parallel position was approximately $0.6 \pm 0.5$ degrees [281]. Da Vinci Surgical Robot (transoral approach) was employed in CMF surgery for the resection of the base of the tongue neoplasm in only 3 patients [282]. The application of robotics for craniotomy is confined to phantom and animal studies [283-285]. A passive robot arm was proposed by Theodossy et al. [92] to improve the model surgery phase during preoperative planning of orthognathic surgery. 


\subsubsection{Minimally Invasive Surgery: Endoscopic Surgery}

Endoscopic surgery in CMF oncological surgery is limited to the resection of osseous tumors [286]. In orthognathic surgery, endoscopically assisted mandibular lengthening with bilateral sagittal split osteotomies and transoral osteosynthesis reduces periosteal degloving and consequent edema. However, the minimal surface available for screw osteosynthesis increases the difficulty of the procedure [287].

Frontal sinus fractures account for 5 to $15 \%$ of all maxillofacial injuries [288].The majority of these fractures are the result of high-impact injuries such as motor vehicle accidents, assaults, and sporting events [288]. The treatment algorithm for complex frontal sinus fractures is controversial due to the associated risks of brain injury, meningitis, cerebrospinal fluid fistula, and mucocele formation [288]. However, mild to moderately displaced anterior table fractures have a relatively low risk of long-term morbidity and are generally treated as esthetic deformities [288]. Unfortunately, the coronal approach for the repair of these injuries is associated with significant sequelae including large scars, alopecia, paresthesias, and, uncommonly, facial nerve injuries [288]. These sequelae may result in greater cosmetic deformities than the initial injury. Consequently, an endoscopic approach to these injuries has recently been proposed [288]. The advantages of endoscopic surgery include limited incisions, reduced soft tissue dissection, reduced risk of alopecia, minimal risk of postoperative paresthesias, reduced hospital stay, and improved patient selection [288]. However, its disadvantages include a moderate learning curve, narrow field of view, lack of depth perception, and the fact that the surgeon cannot operate bimanually without an assistant [288].

Owing to the risk of facial nerve damage and the creation of visible scars, surgical treatment of condylar mandible fractures using an extraoral approach remains controversial [289]. The transoral endoscopically assisted approach for condylar fractures has been reported to avoid these complications [289]. Endoscope-assisted treatment has proved to be more time-consuming but may offer advantages for selected cases, particularly in reducing the occurrence of facial nerve damage [290]. The advancements in miniaturization afford new applications of endoscopy in implantology for intraoperative observations, the assessment of implant sites, and active assistance during implant placement procedures [291]. The major ducts of salivary glands have been explored with a miniaturized sialendoscope, providing a minimally invasive approach for the diagnosis and treatment of obstructive diseases and chronic infections [292].

\section{CONCLUSIONS}

Surgical engineering plays a fundament role in the development and improvement of CMF surgery. The growth in importance of different technologies varies with time. Some technologies have reached maturity and have multiple clinical applications, such as CAS, image-guided navigation, and 3D RP models. Other technologies, such as augmented reality, robotics, and endoscopy require further improvements. Preoperative CAS training has been poorly developed. The existing surgical CMF simulators are in their infancy and are behind advanced pilot simulators. Joint efforts between the surgical and engineering communities should be directed toward integrated surgical simulators for training surgeons for complex surgeries, based on simulations of maxillofacial anatomy, image fusion modalities, and the haptic interface. The most 
pressing issue is to establish effective communication between surgeons and engineers, so that clinical problem encountered by surgeons can be communicated to the engineers and resolved through joint efforts [293].

CONFLICT OF INTEREST: The author declares no conflict of interst.

\section{REFERENCES}

[1] Kim H, Jürgens P, Weber S, Nolte LP, Reyes M. A new soft-tissue simulation strategy for craniomaxillofacial surgery using facial muscle template model. Prog Biophys Mol Biol. 2010; 103(23):284-291.

[2] Barbarino GG, Jabareen M, Trzewik J, Nkengne A, Stamatas G, Mazza E. Development and validation of a three-dimensional finite element model of the face. J Biomech Eng. 2009; 131(4):041006.

[3] Beldie L, Walker B, Lu Y, Richmond S, Middleton J. Finite element modelling of maxillofacial surgery and facial expressions-a preliminary study. Int J Med Robot. 2010; 6(4):422-430.

[4] Wang D, Cheng L, Wang C, Qian Y, Pan X. Biomechanical analysis of rapid maxillary expansion in the UCLP patient. Med Eng Phys. 2009; 31(3):409-417.

[5] Kober C, Stübinger S, Hellmich C, Sader R, Zeilhofer HF. Mandibular finite element simulation as a tool for trauma surgery. Int J Comput Dent. 2008; 11(3-4):175-181.

[6] Korkmaz HH. Evaluation of different miniplates in fixation of fractured human mandible with the finite element method. Oral Surg Oral Med Oral Pathol Oral Radiol Endod. 2007; 103(6):e1-13.

[7] Lovald S, Baack B, Gaball C, Olson G, Hoard A. Biomechanical optimization of bone plates used in rigid fixation of mandibular symphysis fractures. J Oral Maxillofac Surg. 2010; 68(8):1833-1841.

[8] Ji B, Wang C, Liu L, Long J, Tian W, Wang H. A biomechanical analysis of titanium miniplates used for treatment of mandibular symphyseal fractures with the finite element method. Oral Surg Oral Med Oral Pathol Oral Radiol Endod. 2010; 109(3):e21-27.

[9] Cox T, Kohn MW, Impelluso T. Computerized analysis of resorbable polymer plates and screws for the rigid fixation of mandibular angle fractures. J Oral Maxillofac Surg. 2003; 61(4):481-487, discussion 487-488.

[10] Al-Sukhun J, Lindqvist C, Kontio R. Modelling of orbital deformation using finite-element analysis. $J$ R Soc Interface. 2006; 3(7):255-262.

[11] Luboz V, Chabanas M, Swider P, Payan Y. Orbital and maxillofacial computer aided surgery: patientspecific finite element models to predict surgical outcomes. Comput Methods Biomech Biomed Engin. 2005; 8(4):259-265.

[12] Sutradhar A, Paulino GH, Miller MJ, Nguyen TH. Topological optimization for designing patientspecific large craniofacial segmental bone replacements. Proc Natl Acad Sci USA. 2010; 107(30):13222-13227.

[13] Szucs A, Bujtár P, Sándor GK, Barabás J. Finite element analysis of the human mandible to assess the effect of removing an impacted third molar. J Can Dent Assoc. 2010; 76:a72.

[14] van Staden RC, Guan H, Johnson NW, Loo YC, Meredith N. Step-wise analysis of the dental implant insertion process using the finite element technique. Clin Oral Implants Res. 2008; 19(3):303-313.

[15] Huang HL, Fuh LJ, Ko CC, Hsu JT, Chen CC. Biomechanical effects of a maxillary implant in the augmented sinus: a three-dimensional finite element analysis. Int J Oral Maxillofac Implants. 2009; 24(3):455-462.

[16] Remmler D, Olson L, Duke D, Ekstrom R, Matthews D, Ullrich CG. Presurgical finite element analysis from routine computed tomography studies for craniofacial distraction: II. An engineering prediction model for gradual correction of asymmetric skull deformities. Plast Reconstr Surg. 1998; 102(5):1395-1404.

[17] Remmler D, Olson L, Ekstrom R, Duke D, Matamoros A, Matthews D, Ullrich CG. Pre-surgical CT/FEA for craniofacial distraction: I. Methodology, development, and validation of the cranial finite element model. Med Eng Phys. 1998; 20(8):607-619. 
[18] Veziroglu F, Yilmaz D. Biomechanical evaluation of the consolidation period of alveolar distraction osteogenesis with three-dimensional finite element analysis. Int J Oral Maxillofac Surg. 2008; 37(5):448-452.

[19] Edwards SP. Computer-assisted craniomaxillofacial surgery. Oral Maxillofac Surg Clin North Am. 2010; 22(1):117-134. Review.

[20] Meyer U, Stamm T, Meier N, Joos U. First experience with a public domain computer-aided surgical system. Br J Oral Maxillofac Surg. 2002; 40(2):96-104.

[21] Altobelli DE, Kikinis R, Mulliken JB, Cline H, Lorensen W, Jolesz F. Computer-assisted threedimensional planning in craniofacial surgery. Plast Reconstr Surg. 1993; 92(4):576-585, discussion 586-587.

[22] Vander Sloten J, Degryse K, Gobin R, Van der Perre G, Mommaerts MY. Interactive simulation of cranial surgery in a computer aided design environment. J Craniomaxillofac Surg. 1996; 24(2):122129.

[23] Jans G, Vander Sloten J, Gobin R, Van der Perre G, Van Audekercke R, Mommaerts M. Computeraided craniofacial surgical planning implemented in CAD software. Comput Aided Surg. 1999; 4(3):117-128.

[24] Gladilin E, Ivanov A. Computational modelling and optimisation of soft tissue outcome in craniomaxillofacial surgery planning. Comput Methods Biomech Biomed Engin. 2009; 12(3):305-318.

[25] Jayaratne YS, Zwahlen RA, Lo J, Tam SC, Cheung LK. Computer-aided maxillofacial surgery: an update. Surg Innov. 2010; 17(3):217-225. Review.

[26] Erickson KL, Bell WH, Goldsmith DH. Analytical model surgery, in: Bell WH (ed). Modern practice in orthognathic and reconstructive surgery. Saunders, USA, 1992:154-216.

[27] Boutault H, Cadenat H. Stratégie de la décision en chirurgie orthognathique. Rev Stomatol Chir Maxillofac. 1992; 93(1):287-297.

[28] Vesse M. Que reste-t-il de l'examen clinique en chirurgie orthopédique des maxillaires en 1991? Rev Stomatol Chir Maxillofac. 1992; 93(1):13-19.

[29] Rustemeyer J, Groddeck A, Zwerger S, Bremerich A. The accuracy of two-dimensional planning for routine orthognathic surgery. Br J Oral Maxillofac Surg. 2010; 48(4):271-275.

[30] Gateno J, Forrest KK, Camp B. A comparison of three methods of face bow transfer recording: Implications for orthognathic surgery. J Oral Maxillofac Surg. 2001; 59(6):635-640.

[31] Hohl TH. The use of an anatomic articulator in segmental orthognathic surgery. Am J Orthod. 1978; 73(4):428-442.

[32] Ellis E III. Accuracy of model surgery: Evaluation of an old technique and introduction of a new one. J Oral Maxillofac Surg. 1990; 48(11):1161-1167.

[33] Ellis E III. Bimaxillary surgery using an intermediate splint to position the maxilla. J Oral Maxillofac Surg. 1999; 57(1):53-56.

[34] Lapp TH. Bimaxillary surgery without the use of an intermediate splint to position the maxilla. J Oral Maxillofac Surg. 1999; 57(1):57-60.

[35] Bamber MA, Harris M. The role of the occlusal wafer in orthognathic surgery: a comparison of thick and thin intermediate osteotomy wafers. J Craniomaxillofac Surg. 1995; 23(6):396-400.

[36] Delaire J. Pitfalls in the interpretation of cephalometric teleradiography. Rev Stomatol Chir Maxillofac. 1984; 85(3):176-185.

[37] Da Silveira HL, Silveira HE. Reproducibility of cephalometric measurements made by three radiology clinics. Angle Orthod. 2006; 76(3):394-399.

[38] Houston WJB, Maher RE, McElroy D, Sherriff M. Sources of error in measurements from cephalometric radiographs. Eur J Orthod. 1986; 8(3):149-151.

[39] Ongkosuwito EM, Katsaros C, van 't Hof MA, Bodegom JC, Kuijpers-Jagtman AM. The reproducibility of cephalometric measurements: a comparison of analogue and digital methods. Eur $J$ Orthod. 2002; 24(6):655-665. 
[40] Olszewski R, Reychler H. Limitations of orthognathic model surgery: theoretical and practical implications. Rev Stomatol Chir Maxillofac. 2004; 105(3):165-169.

[41] Marko JV. Simple hinge and semiadjustable articulators in orthognathic surgery. Am J Orthod Dentofac Orthop. 1986; 90:37-44.

[42] Nattestad A, Vedtofte P. Pitfalls in orthognathic model surgery. The significance of using different reference lines and points during model surgery and operation. Int J Oral Maxillofac Surg. 1994; 23(1):11-15.

[43] Gil JN, Claus JPD, Manfro R, Lima SM Jr. Predictability of maxillary repositioning during bimaxillary surgery: accuracy of a new technique. Int J Oral Maxillofac Surg. 2007; 36(4):296-300.

[44] Barbenel JC, Paul PE, Khambay BS, Walker FS, Moos KF, Ayoub AF. Errors in orthognathic surgery planning: the effect of inaccurate study model orientation. Int J Oral Maxillofac Surg. 2010; 39(11):1103-1108.

[45] Popat H, Richmond S, Drage NA. New developments in: three-dimensional planning for orthognathic surgery. J Orthod. 2010; 37(2):62-71.

[46] Xia JJ, Gateno J, Teichgraeber JF, Christensen AM, Lasky RE, Lemoine JJ, Liebschner MA. Accuracy of the computer-aided surgical simulation (CASS) system in the treatment of patients with complex craniomaxillofacial deformity: A pilot study. J Oral Maxillofac Surg. 2007; 65(2):248-254.

[47] Gateno J, Xia J, Teichgraeber JF, Rosen A. A new technique for the creation of a computerized composite skull model. J Oral Maxillofac Surg. 2003; 61(2):222-227.

[48] Z'Graggen M, Schiel HJ, Kunz C, Lambrecht JT. Three-dimensional cephalometry using individual skeletal laser technology models. Clin Anat. 2001; 14(4):258-268.

[49] Swennen GR, Mollemans W, Schutyser F. Three-dimensional treatment planning of orthognathic surgery in the era of virtual imaging. J Oral Maxillofac Surg. 2009; 67(10):2080-2092.

[50] Loh S, Yow M. Computer prediction of hard tissue profiles in orthognathic surgery. Int J Adult Orthodon Orthognath Surg. 2002; 17(4):342-347.

[51] Tucker S, Cevidanes LH, Styner M, Kim H, Reyes M, Proffit W, Turvey T. Comparison of actual surgical outcomes and 3-dimensional surgical simulations. J Oral Maxillofac Surg. 2010; 68(10):2412-2421.

[52] Calignano F, Vezzetti E. Soft tissue diagnosis in maxillofacial surgery: a preliminary study on threedimensional face geometrical features-based analysis. Aesthetic Plast Surg. 2010; 34(2):200-211.

[53] Hajeer MY, Ayoub AF, Millett DT, Bock M, Siebert JP. Three-dimensional imaging in orthognathic surgery: the clinical application of a new method. Int J Adult Orthodon Orthognath Surg. 2002; 17(4):318-330.

[54] Naftel AJ, Trenouth MJ. Stereo-assisted landmark detection for the analysis of changes in 3-D facial shape. Med Inform Internet Med. 2004; 29(2):137-155.

[55] Ramieri GA, Spada MC, Nasi A, Tavolaccini A, Vezzetti E, Tornincasa S, Bianchi SD, Verzé L. Reconstruction of facial morphology from laser scanned data. Part I: reliability of the technique. Dentomaxillofac Radiol. 2006; 35(3):158-164.

[56] Ayoub A, Garrahy A, Hood C, White J, Bock M, Siebert JP, Spencer R, Ray A. Validation of a visionbased, three-dimensional facial imaging system. Cleft Palate Craniofac J. 2003; 40(5):523-529.

[57] Lübbers HT, Medinger L, Kruse A, Grätz KW, Matthews F. Precision and accuracy of the 3dMD photogrammetric system in craniomaxillofacial application. J Craniofac Surg. 2010; 21(3):763-767.

[58] Khambay B, Nebel JC, Bowman J, Walker F, Hadley DM, Ayoub A. 3D stereophotogrammetric image superimposition onto 3D CT scan images: the future of orthognathic surgery. A pilot study. Int J Adult Orthodon Orthognath Surg. 2002; 17(4):331-341.

[59] Mischkowski RA, Bongartz J, Giel D, Frey S, Thelen A, Hering P. Holographic face models as planning tool in maxillofacial surgery. Int J Comput Dent. 2004; 7(4):339-345.

[60] Noguchi N, Tsuji M, Shigematsu M, Goto M. An orthognathic simulation system integrating teeth, jaw and face data using 3D cephalometry. Int J Oral Maxillofac Surg. 2007; 36(7):640-645. 
[61] Uechi J, Okayama M, Shibata T, Muguruma T, Hayashi K, Endo K, Mizoguchi I. A novel method for the 3-dimensional simulation of orthognathic surgery by using a multimodal image-fusion technique. Am J Orthod Dentofacial Orthop. 2006; 130(6):786-798.

[62] Swennen GR, Mommaerts MY, Abeloos J, De Clercq C, Lamoral P, Neyt N, Casselman J, Schutyser F. A cone-beam CT based technique to augment the 3D virtual skull model with a detailed dental surface. Int J Oral Maxillofac Surg. 2009; 38(1):48-57.

[63] Nadjmi N, Mollemans W, Daelemans A, Van Hemelen G, Schutyser F, Bergé S. Virtual occlusion in planning orthognathic surgical procedures. Int J Oral Maxillofac Surg. 2010; 39(5):457-462.

[64] Schendel SA, Jacobson R. Three-dimensional imaging and computer simulation for office-based surgery. J Oral Maxillofac Surg. 2009; 67(10):2107-2114.

[65] Westermark A, Zachow S, Eppley BL. Three-dimensional osteotomy planning in maxillofacial surgery including soft tissue prediction. J Craniofac Surg. 2005; 16(1):100-104.

[66] Xia J, Ip HH, Samman N, Wong HT, Gateno J, Wang D, Yeung RW, Kot CS, Tideman H. Threedimensional virtual-reality surgical planning and soft-tissue prediction for orthognathic surgery. IEEE Trans Inf Technol Biome. 2001; 5(2):97-107.

[67] Marchetti C, Bianchi A, Bassi M, Gori R, Lamberti C, Sarti A. Mathematical modeling and numerical simulation in maxillo-facial virtual surgery (VISU). J Craniofac Surg. 2006; 17(4):661-667, discussion 668.

[68] Chang YB, Xia JJ, Gateno J, Xiong Z, Zhou X, Wong ST. An automatic and robust algorithm of reestablishment of digital dental occlusion. IEEE Trans Med Imaging. 2010; 29(9):1652-1663.

[69] Fang JJ, Kuo TH. Modelling of mandibular movement. Comput Biol Med. 2008; 38(11-12):11521162.

[70] Olszewski R, Villamil MB, Trevisan DG, Nedel LP, Freitas CM, Reychler H, Macq B. Towards an integrated system for planning and assisting maxillofacial orthognathic surgery. Comput Methods Programs Biomed. 2008; 91(1):13-21.

[71] De Momi E, Chapuis J, Pappas I, Ferrigno G, Hallermann W, Schramm A, Caversaccio M. Automatic extraction of the mid-facial plane for cranio-maxillofacial surgery planning. Int J Oral Maxillofac Surg. 2006; 35(7):636-642.

[72] Danesh G, Lippold C, Joos U, Meyer U. Technical and clinical assessment of the use of a new material-based splint in orthognathic surgery. Int J Oral Maxillofac Surg. 2006; 35(9):796-799.

[73] Santler G. 3-D COSMOS: a new 3-D model based computerised operation simulation and navigation system. J Craniomaxillofac Surg. 2000; 28(5):287-293.

[74] Reychler A. Notions d'orthopédie dento-maxillo-faciale, in Piette E, Reychler H (eds). Traité de pathologies buccale et maxillo-faciale. De Boeck,, Belgium, 1990:1639-1724.

[75] Tweed CH. Clinical orthodontics, Mosby, Saint Louis, 1960.

[76] Sassouni V, Forrest A . Orthodontics in dental practice, Mosby, Saint Louis, 1971.

[77] Bimler HP. Bimler therapy. Part 1. Bimler cephalometric analysis. J Clin Orthod. 1985; 19(7):501523.

[78] Lippold C, Danesh G, Meyer U, Hohoff A, Kelker M, Kleinheinz J. Potential and limitations of cephalometric analysis of maxillofacial bone movement in the case of LeFort III-distraction. J Orofac Orthop. 2005; 66(5):388-396.

[79] Burstone CJ, James RR, Legan H, Murphy GA, Norton LA. Cephalometrics for orthognathic surgery. J Oral Surg. 1978; 36(4):269-276.

[80] Delaire J. L'analyse architecturale et structurale cranio-faciale (de profil). Principes théoriques. Quelques exemples d'emploi en chirurgie maxillo-faciale. Rev Stomatol. 1978; 79(1):1-33.

[81] Enlow DH. Handbook of facial growth, Saunders, Philadelphia, 1975.

[82] Tsuji M, Nogushi N, Shigematsu M, Yamashita Y, Ihara K, Shikimori M, Goto M. A new navigation system based on cephalograms and dental casts for oral and maxillofacial surgery. Int J Oral Maxillofac Surg. 2006; 35(9):828-836. 
[83] Olszewski R, Cosnard G, Macq B, Mahy P, Reychler H. CT based cephalometric analysis: 3D cephalometric theoretical concept and software. Neuroradiology. 2006; 48(11):853-862.

[84] Bettega G, Payan Y, Mollard B, Boyer A, Raphael B, Lavallee S. A simulator for maxillofacial surgery integrating 3D cephalometry and orthodontia. Comput Aided Surg. 2000; 5(3):156-165.

[85] Olszewski R, Tran Duy K, Raucent B, Reychler H, Nicolas V. Method and equipment for the simulation of the operation of maxillofacial surgery and transfer of this planning to the operating room. EU Patent $n^{\circ} 2705051$.

[86] Treil J, Casteigt J, Borianne P, Madrid C, Jaeger M., de Bonnecaze P. L'équilibre architectural de la face: un concept céphalométrique 3D. Rev Stomatol Chir Maxillofac. 1999; 100(3):111-122.

[87] Gateno J, Teichgraeben JF, Xia J. Method and apparatus for fabricating orthognathic surgical splints. Patent application publication US 2003/0065259 A1.

[88] Wong B. Adjustable occlusal plane table and method of use for orthognathic set-ups. US Patent $n^{\circ}$ 4624639.

[89] Glatt M. Accessory device for a dental articulator and method for use in fabrication of dental prosthetics. US patent $n^{\circ} 5795152$.

[90] Staples RC. Orthognathic surgery simulation instrument. US patent $n^{\circ} 6102698$.

[91] Wiechmann D, Ehmer U, Joos U, Dorr-Neudeck K. Le procédé de double socle calibré préfabriqué KDMMS pour simulation et planification tridimensionnelle dans l'articulateur en chirurgie orthognathique. Rev Stomatol Chir Maxillofac. 1997; 98(2):91-95.

[92] Theodossy T, Bamber MA. Model surgery with passive robot arm for orthognathic surgery planning. J Oral Maxillofac Surg. 2003; 61(11):1310-1317.

[93] Hibi H, Sawaki Y, Ueda M. Three-dimensional model simulation in orthognathic surgery. Int J Adult Orthodon Orthognath Surg. 1997; 12(3):226-232.

[94] Hassfeld S, Mühling J. Computer assisted oral and maxillofacial surgery - a review and an assessment of technology. Int J Oral Maxillofac Surg. 2001; 30(1):2-13.

[95] Troulis MJ, Everett P, Seldin EB, Kikinis R, Kaban LB. Development of a three-dimensional treatment planning system based on computed tomographic data. Int J Oral Maxillofac Surg. 2002; 31(4):349357.

[96] Neumann P, Siebert D, Faulkner G, Krauss M, Schulz A, Lwowsky C, Tolxdorff T. Virtual 3D cutting for bone segment extraction in maxillofacial surgery planning. Stud Health Technol Inform. 1999; 62:235-241.

[97] Xia J, Wang D, Samman N, Yeung RWK, Tideman H. Computer-assisted three dimensional surgical planning and simulation: 3D colour facial model generation. Int J Oral Maxillofac Surg. 2000; 29(4):2-10.

[98] Xia J, Ip HS, Samman N, Wang , Kot CSB, Yeung RWK, Tideman H. Computer-assisted threedimensional surgical planning and simulation: 3D virtual osteotomy. Int J Oral Maxillofac Surg. 2000; 29(4):11-17.

[99] Kau CH, Cronin AJ, Richmond S. A three-dimensional evaluation of postoperative swelling following orthognathic surgery at 6 months. Plast Reconstr Surg. 2007; 119(7):2192-2199.

[100] Soncul M, Bamber MA. Evaluation of facial soft tissue changes with optical surface scan after surgical correction of Class III deformities. J Oral Maxillofac Surg. 2004; 62(11):1331-1340.

[101] Day CJ, Robert T. Three-dimensional assessment of the facial soft tissue changes that occur postoperatively in orthognathic patients. World J Orthod. 2006; 7(1):15-26.

[102] Harrison JA, Nixon MA, Fright WR, Snape L. Use of hand-held laser scanning in the assessment of facial swelling: a preliminary study. Br J Oral Maxillofac Surg. 2004; 42(1):8-17.

[103] Swennen GRJ, Barth EL, Eulzer C, Schutyzer F. The use of a new 3D splint and double CT scan procedure to obtain an accurate anatomic virtual augmented model of the skull. Int J Oral Maxillofac Surg. 2007; 36(2):146-152.

[104] Hassfeld S, Mühling J, Zoller J. Intraoperative navigation in oral and maxillofacial surgery. Int J Oral Maxillofac Surg. 1995; 24(1Pt2):111-119. 
[105] Marmulla R, Lüth T, Mühling J, Hassfeld S. Automated laser registration in image-guided surgery: evaluation of the correlation between laser scan resolution and navigation accuracy. Int J Oral Maxillofac Surg. 2004; 33(7):642-648.

[106] Wagner A, Ploder O, Ensilidis G, Truppe M, Ewers R. Image-guided surgery. Int J Oral Maxillofac Surg. 1996; 25(2):147-151.

[107] Marmulla R, Niederdellmann H. Contrôle de la précision de la position des segments osseux pendant la navigation chirurgicale. Rev Stomatol Chir Maxillofac. 1998; 99(4):184-187.

[108] Shuhaiber JH. Augmented reality in surgery. Arch Surg. 2004; 139(2):170-174.

[109] Cleary K, Nguyen C. State of art in surgical robotics: clinical application and technology challenges. Comput Aided Surg. 2001; 6(6):312-328.

[110] Korb W, Marmulla R, Raczkowsky J, Mühling J, Hassfeld S. Robots in the operating theatre - chances and challenges. Int J Oral Maxillofac Surg. 2004; 33(8):721-732.

[111] Fortin T, Bosson JL, Isidori M, Blanchet E. Effect of flapless surgery on pain experienced in implant placement using an image-guided system. Int J Oral Maxillofac Implants. 2006; 21(2):298-304.

[112] Verstreken K, Van Cleynenbreugel J, Marchal G, Naert I, Suetens P, van Steenberghe D. Computerassisted planning of oral implant surgery: a three-dimensional approach. Int J Oral Maxillofac Implants. 1996; 11(6):806-808.

[113] Ganz SD. Presurgical planning with CT-derived fabrication of surgical guides. J Oral Maxillofac Surg. 2005; 63(9Suppl2):59-71.

[114] Parel SM, Triplett RG. Interactive imaging for implant planning placemcent, and prosthetic construction. J Oral Maxillofac Surg. 2004; 62(9Supp12):41-47.

[115] Rocci A, Martignoni M, Gottlow J. Immediate loading in the maxilla using flapless surgery, implants placed in predetermined positions, and prefabricated provisional restorations: a retrospective 3-year clinical study. Clin Implant Dent Relat Res. 2003; 5(Suppl1):29-36.

[116] Spector L. Computer-aided dental implant planning. Dent Clin North Am. 2008; 52(4):761-775.

[117] Engleke W, Capobianco M. Flapless sinus floor augmentation using endoscopy combined with CT scan-designed surgical templates: method and report of 6 consecutive cases. Int J Oral Maxillofac Implants. 2005; 20(6):891-897.

[118] Chiarelli T, Lamma E, Sansoni T. A fully 3D work context for oral implant planning and simulation. Int J Comput Assist Radiol Surg. 2010; 5(1):57-67.

[119] BouSerhal C, Jacobs R, Quirynen M, van Steenberghe D. Imaging technique selection for the preoperative planning of oral implants: a review of the literature. Clin Implant Dent Relat Res. 2002; 4(3):156-172. Review.

[120] Ito K, Gomi Y, Sato S, Arai Y, Shinoda K. Clinical application of a new compact CT system to assess $3 \mathrm{D}$ images for the preoperative treatment planning of implants in the posterior mandible. A case report. Clin Oral Implants Res. 2001; 12(5):539-542.

[121] Tardieu PB, Vrielinck L, Escolano E. Computer-assisted implant placement. A case report: treatement of the mandible. Int J Oral Maxillofac Implants. 2003; 18(4):599-604.

[122] Yeh S, Monaco EA, Buhite RJ. Using transitional implants as fixation screws to stabilize a surgical template for accurate implant placement: a clinical report. J Prosthet Dent. 2005; 93(6):509-513.

[123] Gaggl A, Schultes G, Santler G, Karcher H. Treatment planning for sinus lift augmentations through use of 3-dimensional milled models derived from computed tomography scans: a report of 3 cases. Oral Surg Oral Med Oral Pathol Oral Radiol Endod. 1998; 86(4):388-392.

[124] Reychler H, Olszewski R. Intracerebral penetration of a zygomatic dental implant and consequent therapeutic dilemmas: case report. Int J Oral Maxillofac Implants. 2010; 25(2):416-418.

[125] Vrielinck L, Politis C, Schepers S, Pauwels M, Naert I. Image-based planning and clinical validation of zygoma and pterygoid implant placement in patients with severe bone atrophy using customized drill guides. Preliminary results from a prospective clinical follow-up study. Int J Oral Maxillofac Surg. 2003; 32(1):7-14. 
[126] Rubio Serrano M, Albalat Estela S, Peñarrocha Diago M, Peñarrocha Diago M. Software applied to oral implantology: update. Med Oral Patol Oral Cir Bucal. 2008; 13(10):E661-665. Review.

[127] Dérand P, Hirsch JM. Virtual bending of mandibular reconstruction plates using a computer-aided design. J Oral Maxillofac Surg. 2009; 67(8):1640-1643.

[128] Zhou LB, Shang HT, He LS, Bo B, Liu GC, Liu YP, Zhao JL. Accurate reconstruction of discontinuous mandible using a reverse engineering/computer-aided design/rapid prototyping technique: a preliminary clinical study. J Oral Maxillofac Surg. 2010; 68(9):2115-2121.

[129] Toro C, Robiony M, Costa F, Zerman N, Politi M. Feasibility of preoperative planning using anatomical facsimile models for mandibular reconstruction. Head Face Med. 2007; 15(3):5.

[130] Santler G, Kärcher H, Ruda C. Indications and limitations of three-dimensional models in craniomaxillofacial surgery. J Craniomaxillofac Surg. 1998; 26(1):11-16.

[131] Cheung LK, Wong MC, Wong LL. Refinement of facial reconstructive surgery by stereo-model planning. Ann R Australas Coll Dent Surg. 2002; 16:129-132.

[132] Choi JY, Choi JH, Kim NK, Kim Y, Lee JK, Kim MK, Lee JH, Kim MJ. Analysis of errors in medical rapid prototyping models. Int J Oral Maxillofac Surg. 2002; 31(1):23-32.

[133] Robiony M, Salvo I, Costa F, Zerman N, Bandera C, Filippi S, Felice M, Politi M. Accuracy of virtual reality and stereolithographic models in maxillo-facial surgical planning. J Craniofac Surg. 2008; 19(2): 482-489.

[133] Chow LK, Cheung LK. The usefulness of stereomodels in maxillofacial surgical management. J Oral Maxillofac Surg. 2007; 65(11):2260-2268.

[134] Sinn DP, Cillo JE Jr, Miles BA. Stereolithography for craniofacial surgery. J Craniofac Surg. 2006; 17(5):869-875. Review.

[135] Toso F, Zuiani C, Vergendo M, Salvo I, Robiony M, Politi M, Bazzocchi M. Usefulness of computed tomography in pre-surgical evaluation of maxillo-facial pathology with rapid prototyping and surgical pre-planning by virtual reality. Radiol Med. 2005; 110(5-6):665-675.

[136] Silva DN, Gerhardt de Oliveira M, Meurer E, Meurer MI, Lopes da Silva JV, Santa-Bárbara A. Dimensional error in selective laser sintering and 3D-printing of models for craniomaxillary anatomy reconstruction. J Craniomaxillofac Surg. 2008; 36(8):443-449.

[137] Berry E, Brown JM, Connell M, Craven CM, Efford ND, Radjenovic A, Smith MA. Preliminary experience with medical applications of rapid prototyping by selective laser sintering. Med Eng Phys. 1997; 19(1):90-96.

[138] Ibrahim D, Broilo TL, Heitz C, de Oliveira MG, de Oliveira HW, Nobre SM, Dos Santos Filho JH, Silva DN. Dimensional error of selective laser sintering, three-dimensional printing and PolyJet models in the reproduction of mandibular anatomy. J Craniomaxillofac Surg. 2009; 37(3):167-173.

[139] Winder J, Bibb R. Medical rapid prototyping technologies: state of the art and current limitations for application in oral and maxillofacial surgery. J Oral Maxillofac Surg. 2005; 63(7): 1006-1015.

[140] Cohen A, Laviv A, Berman P, Nashef R, Abu-Tair J. Mandibular reconstruction using stereolithographic 3-dimensional printing modeling technology. Oral Surg Oral Med Oral Pathol Oral Radiol Endod. 2009; 108(5):661-666.

[141] Schicho K, Figl M, Seemann R, Ewers R, lambrecht JT, Wagner A, Watzinger F, Baumann A, Kainberger F, Fruehwald J, Klug C. Accuracy of treatment planning based on stereolithography in computer assisted surgery. Med Phys. 2006; 33(9):3408-3459.

[142] Bill JS, Reuther JF. Rapid prototyping in planning reconstructive surgery of the head and neck. Review and evaluation of indications in clinical use. Mund Kiefer Gesichtschir. 2004; 8(3):135-153.

[143] Lin CC, Lo LJ, Lee MY, Wong HF, Chen YR. Craniofacial surgical simulation: application of threedimensional medical imaging and rapid prototyping models. Chang Gung Med J. 2001; 24(4): 229238.

[144] Lieger O, Richards R, Liu M, Lloyd T. Computer-assisted design and manufacture of implants in the late reconstruction of extensive orbital fractures. Arch Facial Plast Surg. 2010; 12(3):186-191.

[145] Williams JV, Revington PJ. Novel use of an aerospace selective laser sintering machine for rapid prototyping of an orbital blowout fracture. Int J Oral Maxillofac Surg. 2010; 39(2):182-184. 
[146] Kozakiewicz M, Elgalal M, Loba P, Komuński P, Arkuszewski P, Broniarczyk-Loba A, Stefańczyk L. Clinical application of 3D pre-bent titanium implants for orbital floor fractures. J Craniomaxillofac Surg. 2009; 37(4): 229-234.

[147] Sannomiya EK, Reis SA, Asaumi J, Silva JV, Barbara AS, Kishi K. Clinical and radiographic presentation and preparation of the prototyping model for pre-surgical planning in Apert's syndrome. Dentomaxillofac Radiol. 2006; 35(2): 119-124.

[148] Asaumi J, Kawai N, Honda Y, Shigehara H, Wakasa T, Kishi K. Comparison of three-dimensional computed tomography with rapid prototype models in the management of coronoid hyperplasia. Dentomaxillofac Radiol. 2001; 30(6):330-335.

[149] Bai S, Bo B, Bi Y, Wang B, Zhao J, Liu Y, Feng Z, Shang H, Zhao Y. CAD/CAM surface templates as an alternative to the intermediate wafer in orthognathic surgery. Oral Surg Oral Med Oral Pathol Oral Radiol Endod. 2010; 110(5):e1-e7.

[150] Mavili ME, Canter HI, Saglam-Aydinatay B, Kamaci S, Kocadereli I. Use of three-dimensional medical modeling methods for precise planning of orthognathic surgery. J Craniofac Surg. 2007; 18(4):740-747.

[151] Wong TY, Fang JJ, Chung CH, Huang JS, Lee JW. Comparison of 2 methods of making surgical models for correction of facial asymmetry. J Oral Maxillofac Surg. 2005; 63(2):200-208.

[152] Chen XY, Chen SL, Zhang X, Li JP, Deng W. Accuracy of intraoral vertical ramus osteotomy with a stereolithographic template. Ann Plast Surg. 2011; 66(1):88-91.

[153] Nikzad S, Azari A, Ghassemzadeh A. Modified flapless dental implant surgery for planning treatment in a maxilla including sinus lift augmentation through use of virtual surgical planning and a 3dimensional model. J Oral Maxillofac Surg. 2010; 68(9):2291-2298.

[154] Robiony M. Distraction osteogenesis: a method to improve facial balance in asymmetric patients. $J$ Craniofac Surg. 2010; 21(2):508-512.

[155] Varol A, Basa S. The role of computer-aided 3D surgery and stereolithographic modelling for vector orientation in premaxillary and trans-sinusoidal maxillary distraction osteogenesis. Int J Med Robot. 200; 5(2):198-206.

[156] Sannomiya EK, Silva JV, Brito AA, Saez DM, Angelieri F, Dalben Gda S. Surgical planning for resection of an ameloblastoma and reconstruction of the mandible using a selective laser sintering 3D biomodel. Oral Surg Oral Med Oral Pathol Oral Radiol Endod. 2008; 106(1):e36-e40.

[157] Yeung RW, Samman N, Cheung LK, Zhang C, Chow RL. Stereomodel-assisted fibula flap harvest and mandibular reconstruction. J Oral Maxillofac Surg. 2007; 65(6):1128-1134.

[158] Singare S, Dichen L, Bingheng L, Yanpu L, Zhenyu G, Yaxiong L. Design and fabrication of custom mandible titanium tray based on rapid prototyping. Med Eng Phys. 2004; 26(8):671-676.

[159] Roser SM, Ramachandra S, Blair H, Grist W, Carlson GW, Christensen AM, Weimer KA, Steed MB. The accuracy of virtual surgical planning in free fibula mandibular reconstruction: comparison of planned and final results. J Oral Maxillofac Surg. 2010; 68(11):2824-2832.

[160] He Y, Zhu HG, Zhang ZY, He J, Sader R. Oral Three-dimensional model simulation and reconstruction of composite total maxillectomy defects with fibula osteomyocutaneous flap flow-through from radial forearm flap. Oral Surg Oral Med Oral Pathol Oral Radiol Endod. 2009; 108(6):e6-e12.

[161] Wu T, Engelhardt M, Fieten L, Popovic A, Radermacher K. Anatomically constrained deformation for design of cranial implant: methodology and validation. Med Image Comput Comput Assist Interv. 2006; 9(Pt 1):9-16.

[162] Agner C, Dujovny M, Park H. Delayed minimally invasive cranioplasty. Minim Invasive Neurosurg. 2003; 46(3):186-190.

[163] Fallahi B, Foroutan M, Motavalli S, Dujovny M, Limaye S. Computer-aided manufacturing of implants for the repair of large cranial defects: an improvement of the stereolithography technique. Neurol Res. 1999; 21(3):281-286.

[164] Maravelakis E, David K, Antoniadis A, Manios A, Bilalis N, Papaharilaou Y. Reverse engineering techniques for cranioplasty: a case study. J Med Eng Technol. 2008; 32(2):115-121. 
[165] Chiarini L, Figurelli S, Pollastri G, Torcia E, Ferrari F, Albanese M, Nocini PF. Cranioplasty using acrylic material: a new technical procedure. J Craniomaxillofac Surg. 2004; 32(1):5-9.

[166] Miyake H, Ohta T, Tanaka H. A new technique for cranioplasty with L-shaped titanium plates and combination ceramic implants composed of hydroxyapatite and tricalcium phosphate (Ceratite). Neurosurgery. 2000; 46(2):414-418.

[167] Ekstrand K, Hirsch JM. Malignant tumors of the maxilla: virtual planning and real-time rehabilitation with custom-made R-zygoma fixtures and carbon-graphite fiber-reinforced polymer prosthesis. Clin Implant Dent Relat Res. 2008; 10(1):23-29.

[168] Ciocca L, De Crescenzio F, Fantini M, Scotti R. Rehabilitation of the nose using CAD/CAM and rapid prototyping technology after ablative surgery of squamous cell carcinoma: a pilot clinical report. Int $J$ Oral Maxillofac Implants. 2010; 25(4):808-812.

[169] Zhang S, Liu X, Xu Y, Yang C, Undt G, Chen M, Haddad MS, Yun B. Application of rapid prototyping for temporomandibular joint reconstruction. J Oral Maxillofac Surg. 2011; 69(2):432-438.

[170] Feiyun P, Wei L, Jun C, Xin X, Zhuojin S, Fengguo Y. Simultaneous correction of bilateral temporomandibular joint ankylosis with mandibular micrognathia using internal distraction osteogenesis and 3-dimensional craniomaxillofacial models. J Oral Maxillofac Surg. 2010; 68(3):571577.

[171] Nagy K, Mommaerts MY. Advanced s(t)imulator for cleft palate repair techniques. Cleft Palate Craniofac J. 2009; 46(1):1-5.

[172] Kobayashi M, Nakajima T, Mori A, Tanaka D, Fujino T, Chiyokura H. Three-dimensional computer graphics for surgical procedure learning: Web three-dimensional application for cleft lip repair. Cleft Palate Craniofac J. 2006; 43(3):266-271.

[173] Leser CP, Jepsen SA. A mandibular surgical training model. Gen Dent. 2008; 56(2):149-154.

[174] Lambrecht JT, Berndt D, Christensen AM, Zehnder M. Haptic model fabrication for undergraduate and postgraduate teaching. Int J Oral Maxillofac Surg. 2010; 39(12):1226-1229.

[175] Choi JY, Song KG, Baek SH. Virtual model surgery and wafer fabrication for orthognathic surgery, Int J Oral Maxillofac Surg. 2009; 38(12):1306-1310.

[176] Gateno J, Xia JJ, Teichgraeber JF, Christensen AM, Lemoine JJ, Liebschner MA, Gliddon MJ, Briggs ME.Clinical feasibility of computer-aided surgical simulation (CASS) in the treatment of complex cranio-maxillofacial deformities. J Oral Maxillofac Surg. 2007; 65(4):728-734.

[177] Metzger MC, Hohlweg-Majert B, Schwarz U, Teschner M, Hammer B, Schmelzeisen R. Manufacturing splints for orthognathic surgery using a three-dimensional printer. Oral Surg Oral Med Oral Pathol Oral Radiol Endod. 2008; 105(2):e1-e7.

[178] Olszewski R, Tranduy K, Reychler H. Innovative procedure for computer-assisted genioplasty: threedimensional cephalometry, rapid-prototyping model and surgical splint. Int J Oral Maxillofac Surg. 2010; 39(7):721-724.[179] Clijmans T, Mommaerts M, Gelaude F, Suetens P, Sloten JV. Skull reconstruction planning transfer to the operation room by thin metallic templates: clinical results. J Craniomaxillofac Surg. 2008; 36(2):66-74.

[180] Liu XJ, Gui L, Mao C, Peng X, Yu GY. Applying computer techniques in maxillofacial reconstruction using a fibula flap: a messenger and an evaluation method. J Craniofac Surg. 2009; 20(2):372-377.

[181] Leiggener C, Messo E, Thor A, Zeilhofer HF, Hirsch JM. A selective laser sintering guide for transferring a virtual plan to real time surgery in composite mandibular reconstruction with free fibula osseous flaps. Int J Oral Maxillofac Surg. 2009; 38(2):187-192.

[182] Fortin T, Bosson JL, Coudert JL, Isidori M. Reliability of preoperative planning of an image-guided system for oral implant placement based on 3-dimensional images: an in vivo study. Int J Oral Maxillofac Implants. 2003; 18(6):886-893.

[183] Sarment DP, Sukovic P, Clinthorne N. Accuracy of implant placement with a stereolithographic surgical guide. Int J Oral Maxillofac Implants. 2003; 18(4):571-577.

[184] Arisan V, Karabuda ZC, Ozdemir T. Accuracy of two stereolithographic guide systems for computeraided implant placement: a computed tomography-based clinical comparative study. J Periodontol. 2010; 81(1):43-51. 
[185] Sammartino G, Della Valle A, Marenzi G, Gerbino S, Martorelli M, di Lauro AE, di Lauro F. Stereolithography in oral implantology: a comparison of surgical guides. Implant Dent. 2004; 13(2):133-139.

[186] Teubner E, Rohner D, Deak A, Lorenzon A, Marinello CP. Navigated implant placement using a bone supported CT-guided surgical template. Case report. Schweiz Monatsschr Zahnmed. 2009; 119(12):1211-1234.

[187] Jayme SJ, Muglia VA, de Oliveira RR, Novaes AB. Optimization in multi-implant placement for immediate loading in edentulous arches using a modified surgical template and prototyping: a case report. Int J Oral Maxillofac Implants. 2008; 23(4):759-762.

[188] Arisan V, Karabuda CZ, Ozdemir T. Implant surgery using bone- and mucosa-supported stereolithographic guides in totally edentulous jaws: surgical and post-operative outcomes of computer-aided vs. standard techniques. Clin Oral Implants Res. 2010; 21(9):980-988.

[189] Sohmura T, Kusumoto N, Otani T, Yamada S, Wakabayashi K, Yatani H. CAD/CAM fabrication and clinical application of surgical template and bone model in oral implant surgery. Clin Oral Implants Res. 2009; 20(1):87-93.

[190] Nickenig HJ, Wichmann M, Hamel J, Schlegel KA, Eitner S. Evaluation of the difference in accuracy between implant placement by virtual planning data and surgical guide templates versus the conventional free-hand method - a combined in vivo - in vitro technique using cone-beam CT (Part II). J Craniomaxillofac Surg. 2010; 38(7):488-493.

[191] Chen X, Yuan J, Wang C, Huang Y, Kang L. Modular preoperative planning software for computeraided oral implantology and the application of a novel stereolithographic template: a pilot study. Clin Implant Dent Relat Res. 2010; 12(3):181-193.

[192] van Steenberghe D, Glauser R, Blombäck U, Andersson M, Schutyser F, Pettersson A, Wendelhag I. A computed tomographic scan-derived customized surgical template and fixed prosthesis for flapless surgery and immediate loading of implants in fully edentulous maxillae: a prospective multicenter study. Clin Implant Dent Relat Res. 2005; 7(Suppl 1):S111-S120.

[193] Yong LT, Moy PK. Complications of computer-aided-design/computer-aided-machining-guided (NobelGuide) surgical implant placement: an evaluation of early clinical results. Clin Implant Dent Relat Res. 2008; 10(3):123-127.

[194] De Santis D, Canton LC, Cucchi A, Zanotti G, Pistoia E, Nocini PF. Computer-assisted surgery in the lower jaw: double surgical guide for immediately loaded implants in postextractive sites-technical notes and a case report. J Oral Implantol. 2010; 36(1):61-68.

[195] Mandelaris GA, Rosenfeld AL. Alternative applications of guided surgery: precise outlining of the lateral window in antral sinus bone grafting. J Oral Maxillofac Surg. 2009; 67(11 Suppl):23-30.

[196] Fortin T, Isidori M, Bouchet H. Placement of posterior maxillary implants in partially edentulous patients with severe bone deficiency using CAD/CAM guidance to avoid sinus grafting: a clinical report of procedure. Int J Oral Maxillofac Implants. 2009; 24(1):96-102.

[197] Zhang X, Chen SL, Zhang JM, Chen JL. Fabrication of a surgical template for orbital implant placement: a case report. Int J Oral Maxillofac Implants. 2010; 25(4):826-830.

[198] Widmann G, Stoffner R, Bale R. Errors and error management in image-guided craniomaxillofacial surgery. Oral Surg Oral Med Oral Pathol Oral Radiol Endod. 2009; 107(5):701-715. Review.

[199] Heiland M, Habermann CR, Schmelzle R. Indications and limitations of intraoperative navigation in maxillofacial surgery. J Oral Maxillofac Surg. 2004: 62(9):1059-1063.

[200] Brief J, Edinger D, Hassfeld S, Eggers G. Accuracy of image-guided implantology. Clin Oral Implants Res. 2005; 16(4):495-501.

[201] Hoffmann J, Westendorff C, Schneider M, Reinert S. Accuracy assessment of image-guided implant surgery: an experimental study. Int J Oral Maxillofac Implants. 2005; 20(3):382-386.

[202] Strong EB, Rafii A, Holhweg-Majert B, Fuller SC, Metzger MC. Comparison of 3 optical navigation systems for computer-aided maxillofacial surgery. Arch Otolaryngol Head Neck Surg. 2008; 134(10):1080-1084. 
[203] Wagner A, Schicho K, Birkfellner W, Figl M, Seemann R, König F, Kainberger F, Ewers R. Quantitative analysis of factors affecting intraoperative precision and stability of optoelectronic and electromagnetic tracking systems. Med Phys. 2002; 29(5):905-912.

[204] Rosenow JM, Sootsman WK. Application accuracy of an electromagnetic field-based image-guided navigation system. Stereotact Funct Neurosurg. 2007; 85(2-3):75-81.

[205] Atuegwu NC, Galloway RL. Volumetric characterization of the Aurora magnetic tracker system for image-guided transorbital endoscopic procedures. Phys Med Biol. 2008; 53(16):4355-4368.

[206] Malthan D, Ehrlich G, Stallkamp J, Dammann F, Schwaderer E, Maassen MM. Automated registration of partially defective surfaces by local landmark identification. Comput Aided Surg. 2003; 8(6) 300-309.

[207] Widmann G, Stoffner R, Schullian P, Widmann R, Keiler M, Zangerl A, Puelacher W, Bale RJ. Comparison of the accuracy of invasive and noninvasive registration methods for image-guided oral implant surgery. Int J Oral Maxillofac Implants. 2010; 25(3):491-498.

[208] Luebbers HT, Messmer P, Obwegeser JA, Zwahlen RA, Kikinis R, Graetz KW, Matthews F. Comparison of different registration methods for surgical navigation in cranio-maxillofacial surgery. J Craniomaxillofac Surg. 2008; 36(2):109-116.

[209] Eggers G, Mühling J, Marmulla R. Image-to-patient registration techniques in head surgery. Int J Oral Maxillofac Surg. 2006; 35(12):1081-1095. Review.

[210] Lee JD, Huang CH, Wang ST, Lin CW, Lee ST. Fast-MICP for frameless image-guided surgery. Med Phys. 2010; 37(9):4551-4559.

[211] Ewers R, Schicho K, Truppe M, Seeman R, Reichwein A, Figl M, Wagner A. Computer-aided navigation in dental implantology: 7 years of clinical experience. J Oral Maxillofac Surg. 2004; 62(3):329-334.

[212] Nijmeh AD, Goodger NM, Hawkes D, Edwards PJ, McGurk M. Image-guided navigation in oral and maxillofacial surgery. Br J Oral Maxillofac Surg. 2005; 43(4):294-302.

[213] Siessegger M, Schneider BT, Mischkowski RA, Lazar F, Krug B, Klepser B, Zoller JE. Use of imageguided navigation system in dental implant surgery in anatomically complex operation sites. $J$ Craniomaxillofac Surg. 2001; 29(5):276-281.

[214] Wanschitz F, Birkfellner W, Watzinger F, Schopper C, Patruta S, Kainberger F, Figl M, Kettenbach J, Bergmann H, Ewers R. Evaluation of accuracy of computer-aided intraoperative positioning of endosseous oral implants in the edentulous mandible. Clin Oral Implants Res. 2002; 13(1):59-64.

[215] Wagner A, Wanschitz F, Birkfellner W, Zauza K, Klug C, Schicho K, Kainberger F, Czerny C, Bergmann H, Ewers R. Computer-aided placemcent of endosseous oral implants in patients after ablative tumour surgery: assessment of accuracy. Clin Oral Implants Res. 2003; 14(3):340-348.

[216] Beumer HW, Puscas L. Computer modeling and navigation in maxillofacial surgery. Curr Opin Otolaryngol Head Neck Surg. 2009; 17(4):270-273. Review.

[217] Tepper OM, Sorice S, Hershman GN, Saadeh P, Levine JP, Hirsch D. Use of virtual 3-dimensional surgery in post-traumatic craniomaxillofacial reconstruction. J Oral Maxillofac Surg. 2011; 69(3) 733-741.

[218] Chen X, Lin Y, Wang C, Shen G, Zhang S, Wang X. A surgical navigation system for oral and maxillofacial surgery and its application in the treatment of old zygomatic fractures. Int J Med Robot. 2011; 7(1):42-50.

[219] Ogino A, Onishi K, Maruyama Y. Intraoperative repositioning assessment using navigation system in zygomatic fracture. J Craniofac Surg. 2009; 20(4):1061-1065.

[220] Yu H, Shen G, Wang X, Zhang S. Navigation-guided reduction and orbital floor reconstruction in the treatment of zygomatic-orbital-maxillary complex fractures. J Oral Maxillofac Surg. 2010; 68(1):28-34.

[221] Collyer J. Stereotactic navigation in oral and maxillofacial surgery. Br J Oral Maxillofac Surg. 2010; 48(2):79-83. Review.

[222] Bell RB, Markiewicz MR. Computer-assisted planning, stereolithographic modeling, and intraoperative navigation for complex orbital reconstruction: a descriptive study in a preliminary cohort. J Oral Maxillofac Surg. 2009; 67(12):2559-2570. 
[223] Tao X, Zhu F, Chen W, Zhu S. The application of virtual endoscopy with computed tomography in maxillofacial surgery. Chin Med J (Engl); 2003, 116(5):679-681.

[224] Li WZ, Zhang MC, Li SP, Zhang LT, Huang Y. Application of computer-aided three-dimensional skull model with rapid prototyping technique in repair of zygomatico-orbito-maxillary complex fracture. Int J Med Robot. 2009; 5(2):158-163.

[225] Klug C, Schicho K, Ploder O, Yerit K, Watzinger F, Ewers R, Baumann A, Wagner A. Point-to-point computer-assisted navigation for precise transfer of planned zygoma osteotomies from the stereolithographic model into reality. J Oral Maxillofac Surg. 2006; 64(3):550-559.

[226] Pham AM, Rafii AA, Metzger MC, Jamali A, Strong EB. Computer modeling and intraoperative navigation in maxillofacial surgery. Otolaryngol Head Neck Surg. 2007; 137(4):624-631.

[227] Beumer HW, Puscas L. Computer modeling and navigation in maxillofacial surgery. Curr Opin Otolaryngol Head Neck Surg. 2009; 17(4):270-273. Review.

[228] Schramm A, Suarez-Cunqueiro MM, Rücker M, Kokemueller H, Bormann KH, Metzger MC, Gellrich NC. Computer-assisted therapy in orbital and mid-facial reconstructions. Int J Med Robot. 2009; 5(2):111-124. Review.

[229] Schramm A, Suarez-Cunqueiro MM, Barth EL, Essig H, Bormann KH, Kokemueller H, Rücker M, Gellrich NC. Computer-assisted navigation in craniomaxillofacial tumors. J Craniofac Surg. 2008; 19(4):1067-1074.

[230] Nijmeh AD, Goodger NM, Hawkes D, Edwards PJ, McGurk M. Image-guided navigation in oral and maxillofacial surgery. Br J Oral Maxillofac Surg. 2005; 43(4):294-302. Review.

[231] Ewers R, Schicho K, Undt G, Wanschitz F, Truppe M, Seemann R, Wagner A. Basic research and 12 years of clinical experience in computer-assisted navigation technology: a review. Int J Oral Maxillofac Surg. 2005; 34(1):1-8. Review.

[232] Bell RB. Computer planning and intraoperative navigation in cranio-maxillofacial surgery; Oral Maxillofac Surg Clin North Am. 2010; 22(1):135-156. Review;

[233] Casap N, Wexler A, Eliashar R. Computerized navigation for surgery of the lower jaw: comparison of 2 navigation systems. J Oral Maxillofac Surg. 2008; 66(7):1467-1475.

[234] Voss PJ, Leow AM, Schulze D, Metzger MC, Liebehenschel N, Schmelzeisen R. Navigation-guided resection with immediate functional reconstruction for high-grade malignant parotid tumour at skull base. Int J Oral Maxillofac Surg. 2009; 38(8):886-890.

[235] Lübbers HT, Jacobsen C, Könü D, Matthews F, Grätz KW, Obwegeser JA. Surgical navigation in cranio-maxillofacial surgery: an evaluation on a child with a cranio-facio-orbital tumour. $\mathrm{Br}$ J Oral Maxillofac Surg. 2011; 49(7):532-537.

[236] Feichtinger M, Aigner RM, Santler G, Kärcher H. Case report: fusion of positron emission tomography (PET) and computed tomography (CT) images for image-guided endoscopic navigation in maxillofacial surgery: clinical application of a new technique. J Craniomaxillofac Surg. 2007; 35(67):322-328.

[237] Feichtinger M, Pau M, Zemann W, Aigner RM, Kärcher H. Intraoperative control of resection margins in advanced head and neck cancer using a 3D-navigation system based on PET/CT image fusion. $J$ Craniomaxillofac Surg. 2010; 38(8):589-594.

[238] Reisner LA, King BW, Klein MD, Auner GW, Pandya AK. A prototype biosensor-integrated imageguided surgery system. Int J Med Robot. 2007; 3:82-88.

[239] Casap N, Tarazi E, Wexler A, Sonnenfeld U, Lustmann J. Intraoperative computerized navigation for flapless implant surgery and immediate loading in the edentulous mandible. Int J Oral Maxillofac Implants. 2005; 20(1):92-98.

[240] Gaggl A, Schultes G. Assessment of accuracy of navigated implant placement in the maxilla. Int J Oral Maxillofac Implants. 2002; 17(2):263-270.

[241] Ng FC, Ho KH, Wexler A. Computer-assisted navigational surgery enhances safety in dental implantology. Ann Acad Med Singapore. 2005; 34(5):383-388.

[242] Randelzhofer P, de la Barrera JM, Spielberg M, Kurtz C, Strub JR. Three-dimensional navigation in oral implantology: a preliminary investigation. Int J Periodontics Restorative Dent. 2001; 21(6):617-626. 
[243] Miller RJ, Bier J. Surgical navigation in oral implantology. Implant Dent. 2006; 15(1):41-47.

[244] Fortin T, Isidori M, Blanchet E, Perriat M, Bouchet H, Coudert JL. An image-guided system-drilled surgical template and trephine guide pin to make treatment of completely edentulous patients easier: a clinical report on immediate loading. Clin Implant Dent Relat Res. 2004; 6(2):111-119.

[245] Casap N, Wexler A, Lustmann J. Image-guided navigation system for placing dental implants. Compend Contin Educ Dent. 2004; 25(10):783-784, 786, 788.

[246] Wexler A, Tzadok S, Casap N. Computerized navigation surgery for the safe placement of palatal implants. Am J Orthod Dentofacial Orthop. 2007; 131(4 Suppl):S100-S105.

[247] Verma SN, Schow SR, Stone BH, Triplett RG. Applications of surgical navigational systems for craniofacial bone-anchored implant placement. Int J Oral Maxillofac Implants. 2010; 25(3):582-588.

[248] Xiaojun C, Ming Y, Yanping L, Yiqun W, Chengtao W. Image guided oral implantology and its application in the placement of zygoma implants. Comput Methods Programs Biomed. 2009; 93(2):162-173.

[249] Xia JJ, Gateno J, Teichgraeber JF. A new paradigm for complex midface reconstruction: a reversed approach. J Oral Maxillofac Surg. 2009; 67(3):693-703.

[250] Mazzoni S, Badiali G, Lancellotti L, Babbi L, Bianchi A, Marchetti C. Simulation-guided navigation: a new approach to improve intraoperative three-dimensional reproducibility during orthognathic surgery. J Craniofac Surg. 2010; 21(6):1698-1705.

[251] Matsuo A, Kono M, Toyoda J, Nakai T, Tsuzuki M, Chiba H. Navigation surgery for Le Fort 1 osteotomy in a fibrous dysplasia patient. Odontology. 2010; 98(2):181-184.

[252] Yu HB, Shen GF, Zhang SL, Wang XD, Wang CT, Lin YP. Navigation-guided gap arthroplasty in the treatment of temporomandibular joint ankylosis. Int J Oral Maxillofac Surg. 2009; 38(10):1030-1035.

[253] Wagner A, Undt G, Watzinger F, Wanschitz F, Schicho K, Yerit K, Kermer C, Birkfellner W, Ewers R. Principles of computer-assisted arthroscopy of the temporomandibular joint with optoelectronic tracking technology. Oral Surg Oral Med Oral Pathol Oral Radiol Endod. 2001; 92(1):30-37.

[254] Belli E, Matteini C, D’Andrea GC, Mazzone N. Navigator system guided endoscopic intraoral approach for remodelling of mandibular condyle in Garré syndrome. J Craniofac Surg. 2007; 18(6):1410-1415.

[255] Lübbers HT, Matthews F, Zemann W, Grätz KW, Obwegeser JA, Bredell M. Registration for computer-navigated surgery in edentulous patients: A problem-based decision concept. $J$ Craniomaxillofac Surg. 2011; 39(6):453-458.

[256] Hoppe H, Salb T, Raczkowsky J, Hassfeld S, Moctezuma JL, Wörn H, Dillmann R. Expanded reality in head surgery. Biomed Tech (Berl). 2002; 47(Suppl1Pt2):946-949.

[257] Mischkowski RA, Zinser MJ, Kübler AC, Krug B, Seifert U, Zöller JE._Application of an augmented reality tool for maxillary positioning in orthognathic surgery - a feasibility study. J Craniomaxillofac Surg. 2006; 34(8):478-483.

[258] Filipo R, Pichi B, Bertoli GA, De Seta E. Video-based system for intraoperative facial nerve monitoring: comparison with electromyography. Otol Neurotol. 2002; 23(4):594-597.

[259] Poukens J, Haex J, Riediger D. The use of rapid prototyping in the preoperative planning of distraction osteogenesis of the cranio-maxillofacial skeleton. Comput Aided Surg. 2003; 8(3):146-154.

[260] Mitsugi M, Ito O, Alcalde RE. Maxillary bone transportation in alveolar cleft-transport distraction osteogenesis for treatment of alveolar cleft repair. Br J Plast Surg. 2005; 58(5):619-625.

[261] Cavaliere CM, Buchman SR. Mandibular distraction in the absence of an ascending ramus and condyle. J Craniofac Surg. 2002; 13(4):527-532.

[262] Yamaji KE, Gateno J, Xia JJ, Teichgraeber JF. New internal Le Fort I distractor for the treatment of midface hypoplasia. J Craniofac Surg. 2004; 15(1):124-127.

[263] Gaggl A, Schultes G, Santler G, Kärcher H. Three-dimensional planning of alveolar ridge distraction by means of distraction implants. Comput Aided Surg. 2000; 5(1):35-41.

[264] Kanno T, Mitsugi M, Sukegawa S, Hosoe M, Furuki Y. Computer-simulated bi-directional alveolar distraction osteogenesis. Clin Oral Implants Res. 2008; 19(12):1211-1218. 
[265] Minoretti R, Triaca A, Antonini M, Merz B. Intra-oral multiaxis mandubular distraction osteogenesis. Clinical analysis of the first six years, in Bell Guerrero (eds). Distraction osteogenesis of the facial skeleton, BC Decker Ed, 2007:359-372.

[266] Tharanon W, Sinn DP. Mandibular distraction osteogenesis with multidirectional extraoral distraction device in hemifacial microsomia patients: three-dimensional treatment planning, prediction tracings, and case outcomes. J Craniofac Surg. 1999; 10(3):202-213.

[267] Dorfman DW, Ciminello FS, Wong GB. Craniofacial distractor applicator. J Craniofac Surg. 2009; 20(2):475-477.

[268] Gateno J, Teichgraeber JF, Xia JJ. Three-dimensional surgical planning for maxillary and midface distraction osteogenesis, J Craniofac Surg. 2003; 14(6):833-839.

[269] Yeshwant K, Seldin EB, Gateno J, Everett P, White CL, Kikinis R, Kaban LB, Troulis MJ. Analysis of skeletal movements in mandibular distraction osteogenesis. J Oral Maxillofac Surg. 2005; 63(3):335-340.

[270] Robiony M, Salvo I, Costa F, Zerman N, Bazzocchi M, Toso F, Bandera C, Filippi S, Felice M, Politi M. Virtual reality surgical planning for maxillofacial distraction osteogenesis: the role of reverse engineering rapid prototyping and cooperative work. J Oral Maxillofac Surg. 2007; 65(6):1198-1208.

[271] Kofod T, Pedersen TK, Nørholt SE, Jensen J. Stereolithographic models for simulation and transfer of vector in vertical distraction of the mandibular ramus: a technical note. J Craniofac Surg. 2005; 16(4):608-614.

[272] Yamada A, Imai K, Nomachi T, Fujimoto T, Sakamoto H, Kitano S. Cranial distraction for plagiocephaly: quantitative morphologic analyses of cranium using three-dimensional computed tomography and a life-size model. J Craniofac Surg. 2005; 16(4):688-693.

[273] Minami K, Mori Y, Tae-Geon K, Shimizu H, Ohtani M, Yura Y. Maxillary distraction osteogenesis in cleft lip and palate patients with skeletal anchorage. Cleft Palate Craniofac J. 2007; 44(2):137-141.

[274] Whitman DH, Connaughton B. Model surgery prediction for mandibular midline distraction osteogenesis. Int J Oral Maxillofac Surg. 1999; 28(6):421-423.

[275] Kofod T, Nørholt SE, Pedersen TK, Jensen J. Reliability of distraction vector transfer in unilateral vertical distraction of the mandibular ramus. J Craniofac Surg. 2005; 16(1):15-22.

[276] Lübbers HT, Messmer P, Grätz KW, Ellis RE, Matthews F. Misjudgments at the mandibular angle: freehand versus computer-assisted screw positioning. J Craniofac Surg. 2010; 21(4):1012-1017.

[277] Lübbers HT, Kruse A, Messmer P, Grätz KW, Obwegeser JA, Matthews F. Precise screw positioning at the mandibular angle: computer assisted versus template coded. J Craniofac Surg. 2011; 22(2):620-624.

[278] Korb W, Engel D, Boesecke R, Eggers G, Kotrikova B, Marmulla R, Raczkowsky J, Wörn H, Mühling J, Hassfeld S. Development and first patient trial of a surgical robot for complex trajectory milling. Comput Aided Surg. 2003; 8(5):247-256.

[279] Fortin T, Champleboux G, Bianchi S, Buatois H, Coudert JL. Precision of transfer of preoperative planning for oral implants based on cone-beam CT-scan images through a robotic drilling machine. Clin Oral Implants Res. 2002; 13(6):651-656.

[280] Schermeier O, Lueth T, Glagau J, Szymanski D, Tita R, Hildebrand D, Klein M, Nelson K, Bier J. Automatic patient registration in computer assisted maxillofacial surgery. Stud Health Technol Inform. 2002; 85:461-467.

[281] Klein M, Hein A, Lueth T, Bier J. Robot-assisted placement of craniofacial implants. Int J Oral Maxillofac Implants. 2003; 18(5):712-718.

[282] O’Malley BW Jr, Weinstein GS, Snyder W, Hockstein NG. Transoral robotic surgery (TORS) for base of tongue neoplasms. Laryngoscope. 2006; 116(8):1465-1472.

[283] Kane G, Eggers G, Boesecke R, Raczkowsky J, Wörn H, Marmulla R, Mühling J. System design of a hand-held mobile robot for craniotomy. Med Image Comput Comput Assist Interv. 2009; 12(Pt1):402-409.

[284] Bast P, Popovic A, Wu T, Heger S, Engelhardt M, Lauer W, Radermacher K, Schmieder K. Robot- and computer-assisted craniotomy: resection planning, implant modelling and robot safety. Int $J$ Med Robot. 2006; 2(2):168-178. 
[285] Eggers G, Wirtz C, Korb W, Engel D, Schorr O, Kotrikova B, Raczkowsky J, Wörn H, Mühling J, Hassfeld S, Marmulla R. Robot-assisted craniotomy. Minim Invasive Neurosurg. 2005; 48(3):154-158.

[286] Chen CT, Adriane K. Endoscopic resection of a mandibular body and condylar osteoma. Minim Invasive Ther Allied Technol. 2008; 17(5):323-325.

[287] Mommaerts MY. Endoscopically assisted sagittal split osteotomy for mandibular lengthening: technical note and initial experience. J Craniomaxillofac Surg. 2010; 38(2):108-112.

[288] Strong EB. Endoscopic repair of anterior table frontal sinus fractures. Facial Plast Surg. 2009; 25(1):43-48.

[289] Lauer G, Pradel W, Schneider M, Eckelt U. A new 3-dimensional plate for transoral endoscopicassisted osteosynthesis of condylar neck fractures. J Oral Maxillofac Surg. 2007; 65(5):964-971.

[290] Schmelzeisen R, Cienfuegos-Monroy R, Schön R, Chen CT, Cunningham L Jr, Goldhahn S. Patient benefit from endoscopically assisted fixation of condylar neck fractures—a randomized controlled trial. J Oral Maxillofac Surg. 2009; 67(1):147-158.

[291] Nahlieli O, Moshonov J, Zagury A, Michaeli E, Casap N. Endoscopic approach to dental implantology. J Oral Maxillofac Surg. 2011; 69(1):186-191.

[292] Turner MD. Sialoendoscopy and salivary gland sparing surgery. Oral Maxillofac Surg Clin North Am. 2009; 21(3):323-329.

[293] Olszewski R, Tran Duy K, Raucent B, Hebda A, Reychler H. Communicating a clinical problem to the engineers: towards a common methodology. Int J Oral Maxillofac Surg. 2008; 37(3):269-274. 


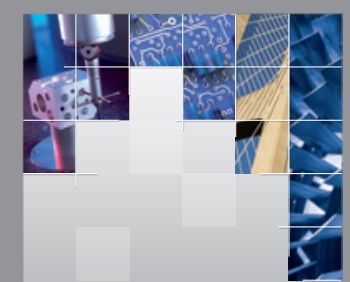

\section{Enfincering}
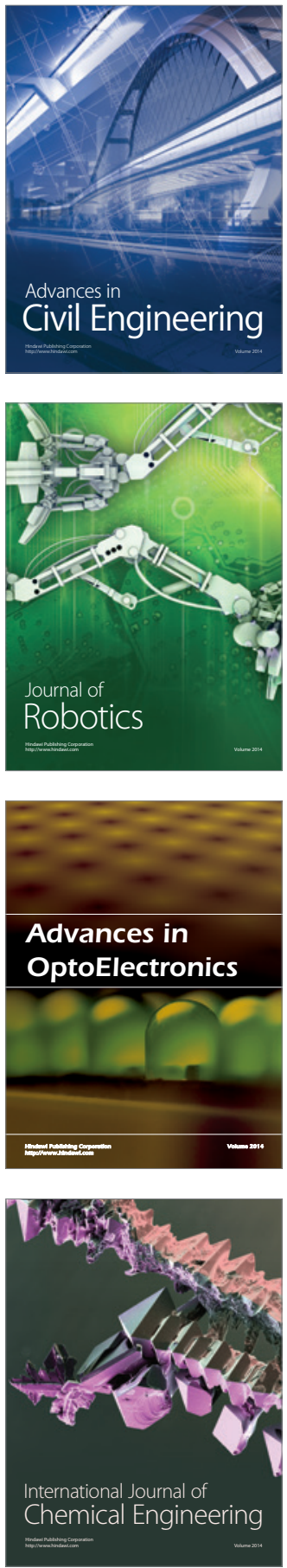

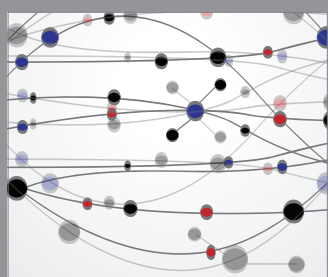

The Scientific World Journal

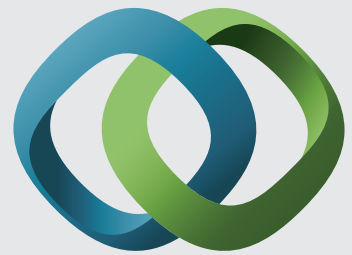

\section{Hindawi}

Submit your manuscripts at

http://www.hindawi.com
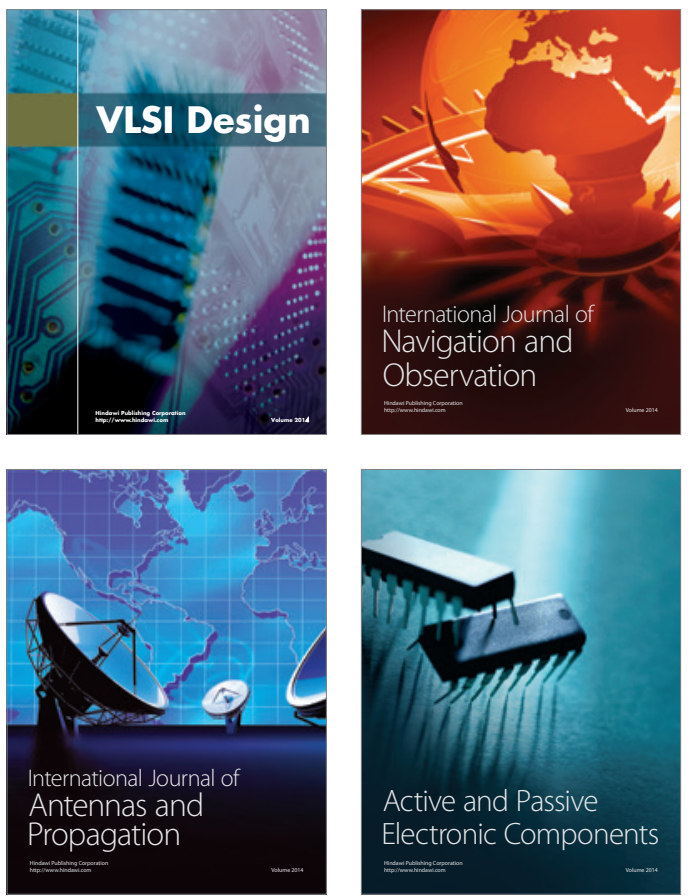
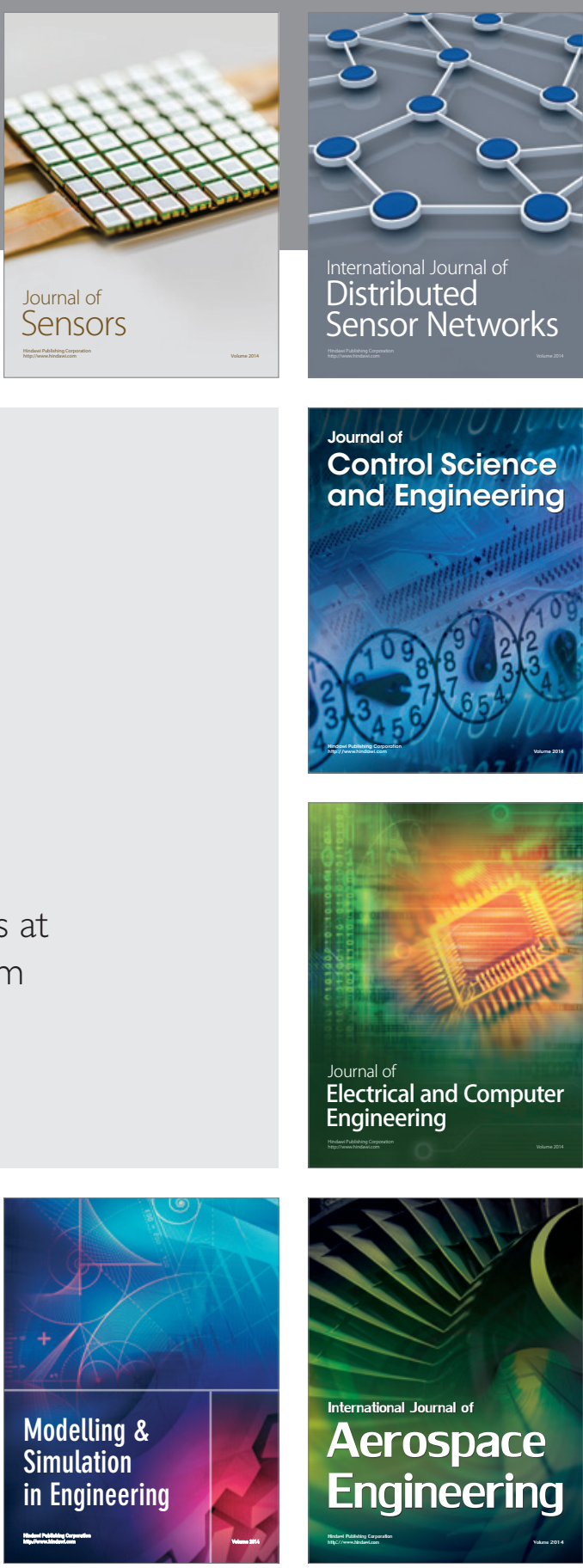

International Journal of

Distributed

Sensor Networks

Journal of

Control Science

and Engineering
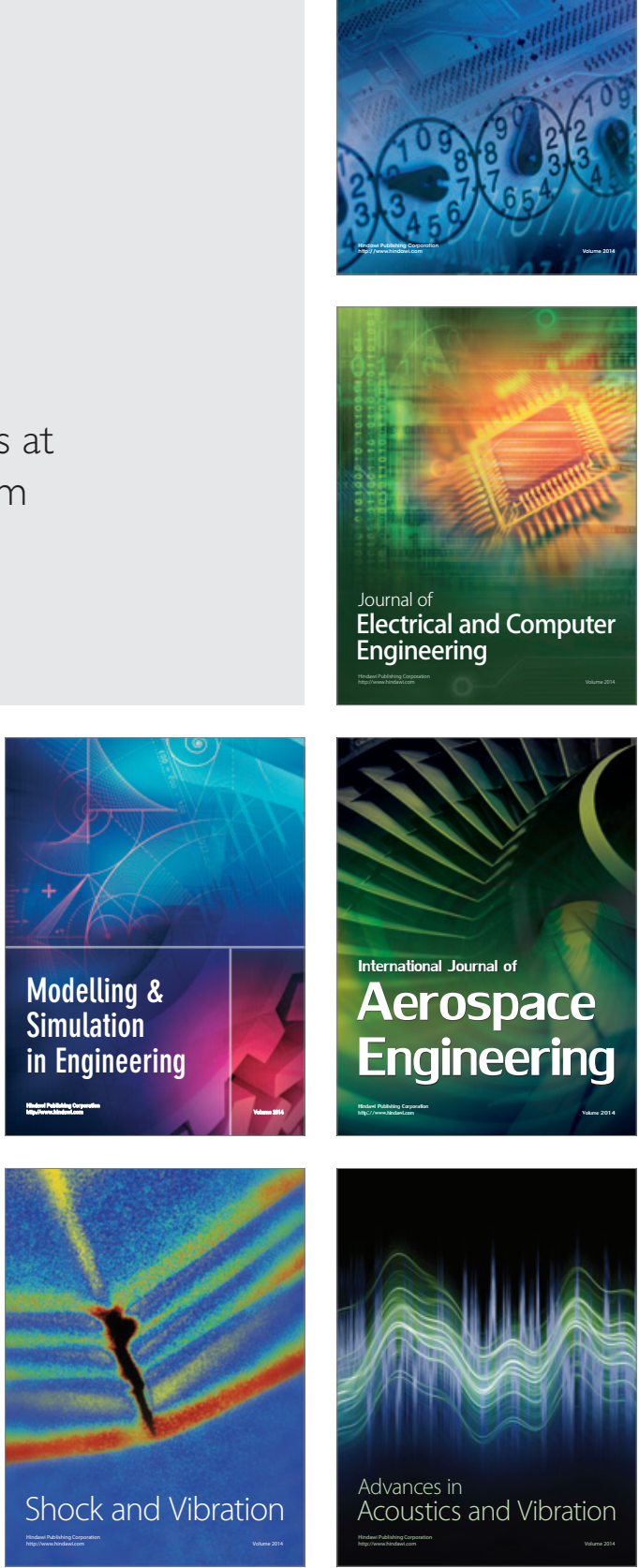